\title{
Process analysis of regional ozone formation over the Yangtze River Delta, China using the Community Multi-scale Air Quality modeling system
}

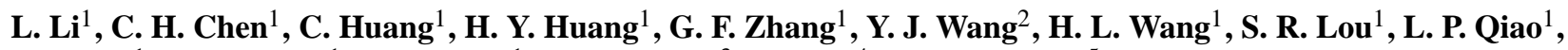 \\ M. Zhou ${ }^{1}$, M. H. Chen ${ }^{1}$, Y. R. Chen ${ }^{1}$, D. G. Streets ${ }^{3}$, J. S. Fu ${ }^{4}$, and C. J. Jang ${ }^{5}$ \\ ${ }^{1}$ Shanghai Academy of Environmental Sciences, Shanghai, 200233, China \\ ${ }^{2}$ Institute of Environmental Pollution and Health, School of Environmental and Chemical Engineering, Shanghai University, \\ Shanghai 200444, China \\ ${ }^{3}$ Decision and Information Sciences Division, Argonne National Laboratory, Argonne, IL 60439, USA \\ ${ }^{4}$ Department of Civil \& Environmental Engineering, University of Tennessee, Knoxville, TN 37996, USA \\ ${ }^{5}$ Office of Air Quality Planning \& Standards, US Environmental Protection Agency, Research Triangle Park, NC 27711, USA
}

Correspondence to: C. H. Chen (chench@saes.sh.cn)

Received: 20 April 2012 - Published in Atmos. Chem. Phys. Discuss.: 13 June 2012

Revised: 20 October 2012 - Accepted: 5 November 2012 - Published: 21 November 2012

\begin{abstract}
A high $\mathrm{O}_{3}$ episode was detected in urban Shanghai, a typical city in the Yangtze River Delta (YRD) region in August 2010. The CMAQ integrated process rate method is applied to account for the contribution of different atmospheric processes during the high pollution episode. The analysis shows that the maximum concentration of ozone occurs due to transport phenomena, including vertical diffusion and horizontal advective transport. Gas-phase chemistry producing $\mathrm{O}_{3}$ mainly occurs at the height of $300-1500 \mathrm{~m}$, causing a strong vertical $\mathrm{O}_{3}$ transport from upper levels to the surface layer. The gas-phase chemistry is an important sink for $\mathrm{O}_{3}$ in the surface layer, coupled with dry deposition. Cloud processes may contribute slightly to the increase of $\mathrm{O}_{3}$ due to convective clouds or to the decrease of $\mathrm{O}_{3}$ due to scavenging. The horizontal diffusion and heterogeneous chemistry contributions are negligible during the whole episode. Modeling results show that the $\mathrm{O}_{3}$ pollution characteristics among the different cities in the YRD region have both similarities and differences. During the buildup period, the $\mathrm{O}_{3}$ starts to appear in the city regions of the YRD and is then transported to the surrounding areas under the prevailing wind conditions. The $\mathrm{O}_{3}$ production from photochemical reaction in Shanghai and the surrounding area is most significant, due to the high emission intensity in the large city; this ozone is then transported out to sea by the westerly wind flow, and later
\end{abstract}

diffuses to rural areas like Chongming island, Wuxi and even to Nanjing. The $\mathrm{O}_{3}$ concentrations start to decrease in the cities after sunset, due to titration of the NO emissions, but ozone can still be transported and maintain a significant concentration in rural areas and even regions outside the YRD region, where the NO emissions are very small.

\section{Introduction}

With the rapid economic development and significant increase of energy consumption, the anthropogenic emissions have been continuously growing in recent years in eastern China, which have led to significant changes in atmospheric ozone, including the increase in tropospheric ozone. More and more concerns have been focused on the regional pollution in those leading economic regions, for example, the Yangtze River delta (Li et al., 2011a; Wang et al., 2005; Zhao et al., 2004), the Pearl River delta (Shen et al., 2011; Wang et al., 2010b), and the Bohai Bay region (An et al, 2007; Chou et al., 2011; Wang et al., 2006, 2009b, 2010a). In recent years, high ozone concentrations over $90 \mathrm{ppb}$ have been frequently observed by in-situ monitoring in eastern China (Ran et al., 2009; Shao et al., 2009; Tang et al., 2009; Zhang et al., 2008). In many megacities and polluted areas in

Published by Copernicus Publications on behalf of the European Geosciences Union. 


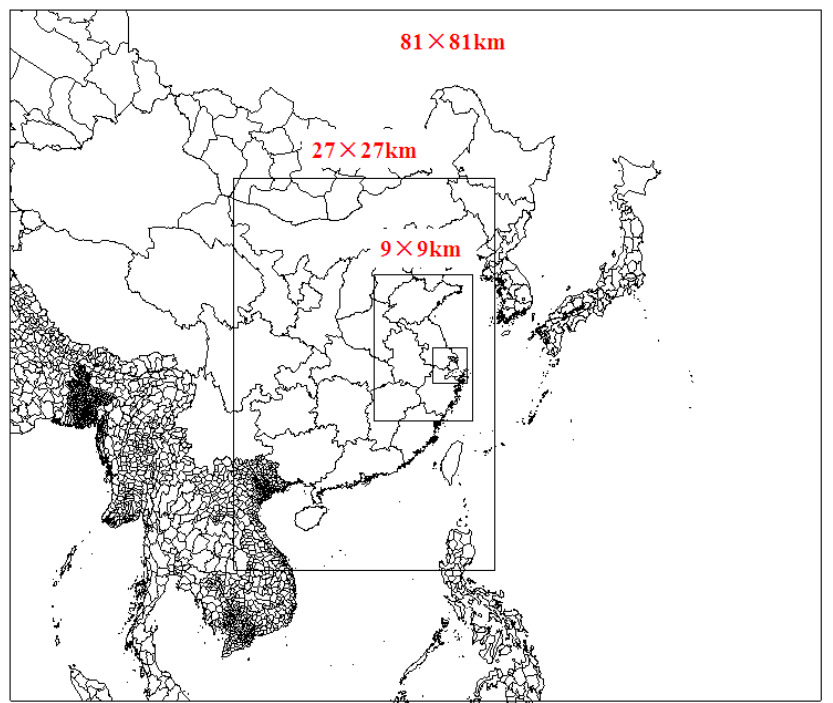

Fig. 1. One-way nested CMAQ model domain.

eastern China, serious ozone pollution caused by high precursor emissions has concerned the citizens and decisionmakers (Shao et al., 2009).

Ozone originates from in-situ photochemical production in the reactions from the mixture of reactive volatile organic compounds (VOC) and nitrogen oxides $\left(\mathrm{NO}_{\mathrm{x}}\right)$ and from vertical and horizontal transport. In the troposphere, photolysis of ozone by solar UV radiation to electronically excited $\mathrm{O}\left({ }^{1} \mathrm{D}\right)$ and the subsequent reaction with water vapor is the major source of the hydroxyl radical $(\mathrm{OH})$. $\mathrm{OH}$ is one of the key species for the chemical reactions in the atmosphere and its abundance is an important index of the oxidizing capacity of the atmosphere. Thus, the control of $\mathrm{O}_{3}$ is a complicated problem due to the nature of the non-linear formation of $\mathrm{O}_{3}$ (Seinfeld and Pandis, 2006).

The Yangtze River Delta (YRD), characterized by high population density and well-developed industry, is one of the largest economic regions in China. Many studies related to the ozone concentration in the YRD have been conducted in the past years. Observations made by Xu et al. (2006) show that high ozone concentrations in the YRD have occurred. Xu et al. (2007) analyzed the tropospheric ozone using satellite data and found that the tropospheric ozone concentration has kept on increasing in the YRD. However, since the YRD is a large area, the emission rates and emission characteristics of the ozone precursors vary greatly. This means that the ozone formation process differs for different areas in the region. Studies on the process analysis of high ozone episodes over the YRD are quite limited up to now.

In this study, we first perform an observational analysis to identify a special summertime $\mathrm{O}_{3}$ episode over the YRD in 2010. Then the Community Multi-scale Air Quality Modeling System (CMAQ) (Byun and Schere, 2006; Foley et al., 2010) is used to reproduce the high ozone case, and integrated process rate analysis (IPR), implemented within CMAQ, is applied to analyze the formation of ozone at typical sites in the YRD. This is undertaken to identify the dominant processes contributing to the $\mathrm{O}_{3}$ formation and to determine the characteristics of the photochemical system at different locations or at a given location on different days.

\section{Methodology}

\subsection{Model setup and input data}

In this paper, the CMAQ version 4.6 is used with the Carbon Bond 05 (CB05) chemical mechanism to simulate the high ozone episode in the YRD in 2010. The CMAQ model domain is based on a Lambert Conformal map projection, using a one-way nested mode with grid resolutions of $81 \mathrm{~km}$ (covering the whole of China, Japan, Korea, parts of India and Southeast Asia); $27 \mathrm{~km}$ (covering eastern China) and $9 \mathrm{~km}$ (covering major city-clusters including Shandong province, the YRD and the Pearl River Delta (PRD)). The large domain is centered at $\left(118^{\circ} \mathrm{E}, 32^{\circ} \mathrm{N}\right)$. The model domain is shown in Fig. 1. The MM5 domain is larger than the CMAQ domain, with three grids more than the CMAQ domain on each boundary. The time period chosen for simulation is month of August 2010, when the YRD experienced high ozone concentrations. A spin-up of 4 days is used to minimize the influence of initial conditions (IC). The boundary condition (BC) used for the largest domain of CMAQ is clean air, while the $\mathrm{BCs}$ for the nested domains are extracted from the CMAQ Chemical Transport Model (CCTM) concentration files of the larger domain. The number of vertical tropospheric levels used in CMAQ is 14 from the surface up to 500hpa. The vertical resolution of the 14 layers corresponds to sigma levels of $1.000,0.995,0.988,0.980,0.970,0.956,0.938,0.893$, $0.839,0.777,0.702,0.582,0.400,0.200$, and 0.000 at the boundaries of the layers.

Previous studies (e.g., Jiménez et al., 2007) have shown that the impact of IC for ground-level ozone is negligible after a 2-day spin-up period. For the boundary conditions, according to Borge's research (Borge et al., 2010), CMAQ model sensitivity to $\mathrm{BC}$ for $\mathrm{NO}_{2}$ and $\mathrm{SO}_{2}$ is small, and the CMAQ nesting approach performs better than the others in prediction of $\mathrm{NO}_{2}$. However, significant domain-wide differences were found when modeling $\mathrm{O}_{3}$ depending on the BC. Related studies show that model-derived, dynamic BC improved the CMAQ predictions when compared to those based on static concentrations prescribed at the boundaries. Aggregated statistics suggest that the GEOS-Chem model produced the best results for $\mathrm{O}_{3}$ and $\mathrm{PM}_{2.5}$ while $\mathrm{NO}_{2}$ and $\mathrm{PM}_{10}$ were slightly better predicted under the CMAQ nesting approach. In this paper, the largest CMAQ domain covers the whole of China, Japan, Korea, parts of India and Southeast Asia, and we use 4-day spin-up period, so the influence of long range transport from outside the largest domain is not 

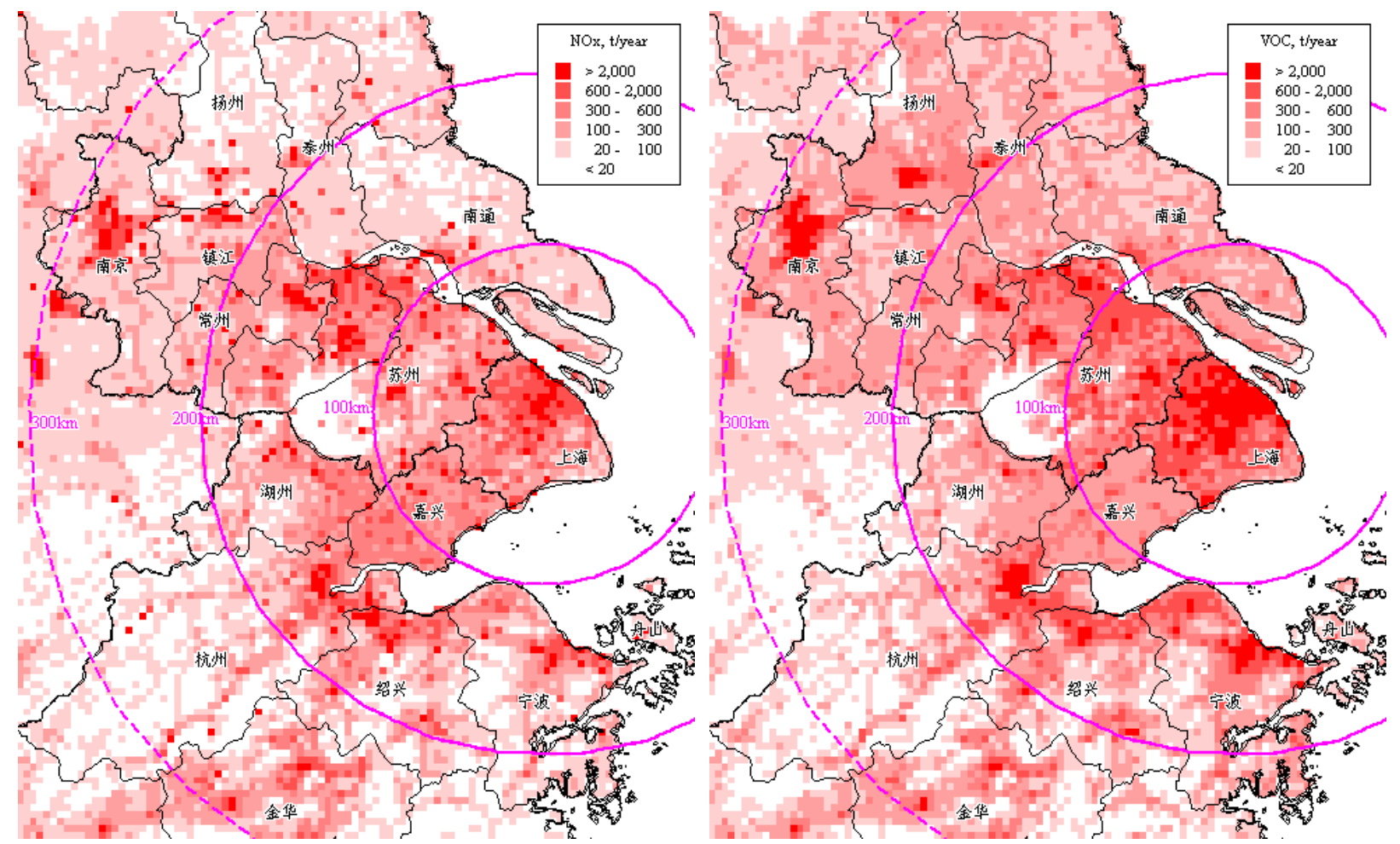

Fig. 2. Emission distribution of $\mathrm{NO}_{\mathrm{x}}(\mathrm{left})$ and $\mathrm{VOC}($ right $)$ in the Yangtze River Delta.
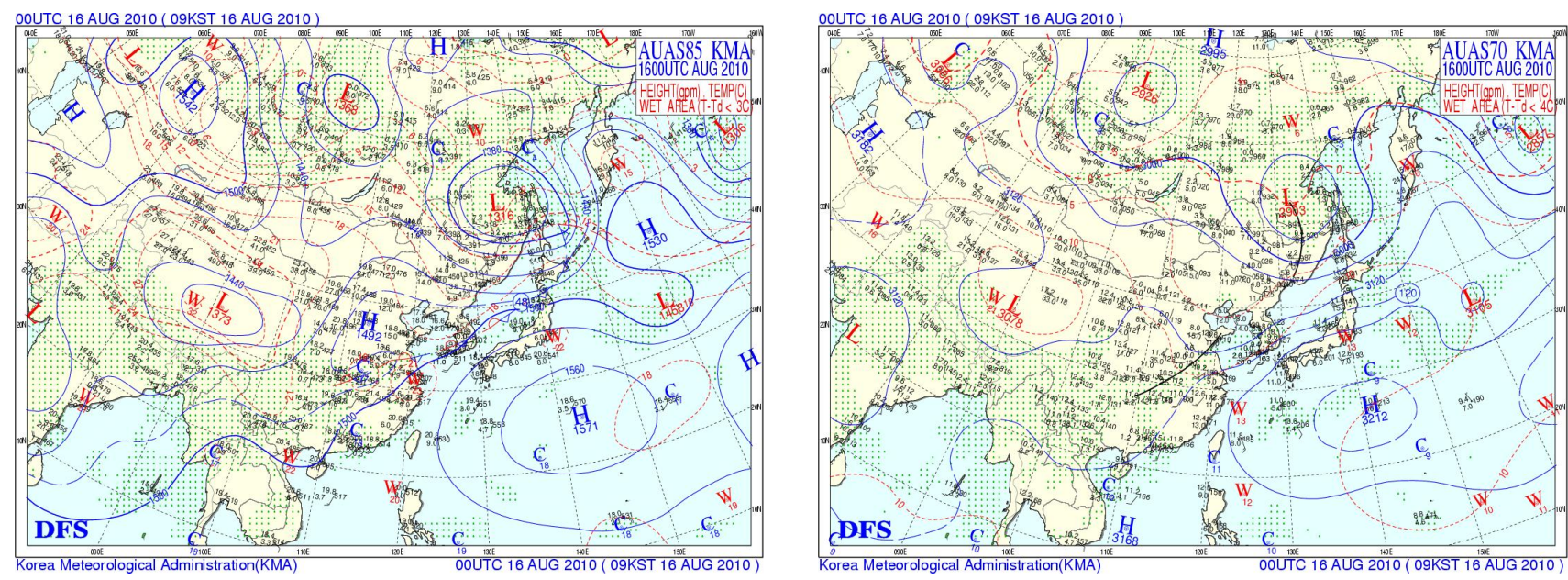

Fig. 3. Weather patterns at $850 \mathrm{hpa}$ (left) and $700 \mathrm{hpa}$ (right) over the eastern Asia at 8:00 a.m. on 16 August 2010 (from Korea Meteorological Administration)

significant for $\mathrm{O}_{3}$ compared to the influences from local and regional emissions.

The driving meteorological inputs for CMAQ are provided by the fifth-generation Pennsylvania State University/National Center for Atmospheric Research (PSU/NCAR) Mesoscale Modeling System (MM5, Version 3.4) with four-dimensional data assimilation (FDDA). The inputs for MM5 are NCEP FNL (Final) Opera- tional Global Analysis data, which are available on $1.0 \times 1.0$ degree grids continuously for every six hours (http://dss.ucar.edu/datasets/ds083.2/). The physical options used in MM5 include the Dudhia simple ice microphysics scheme, the Grell cumulus parameterization scheme, the Medium Range Forecast (MRF) PBL scheme, and the Dudhia cloud radiation scheme. The meteorology-chemistry interface processor (MCIP) is used to transfer MM5 output 

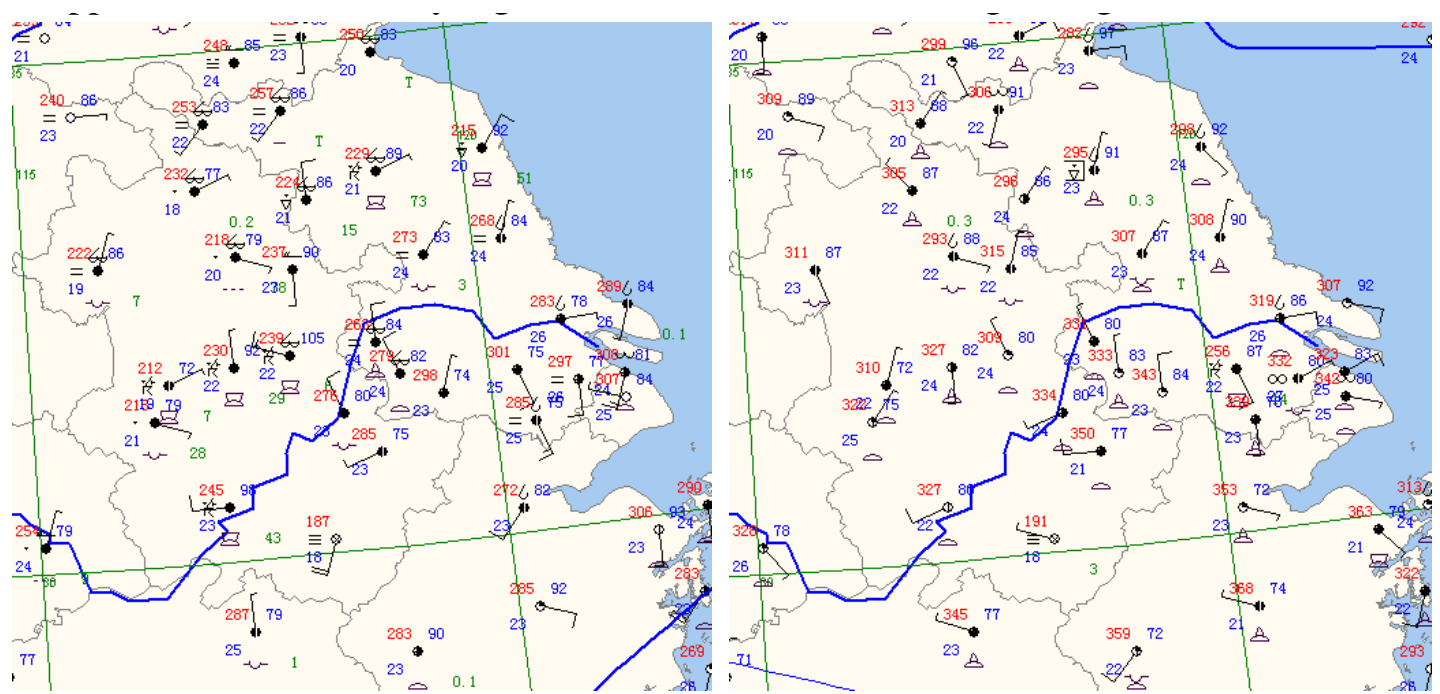

Fig. 4. Pressure field at 08:00 LST on 16 August (left) and 14:00 LST on 17 August (right) (from Meteorological Information Comprehensive Analysis and Process System (MICAPS)).
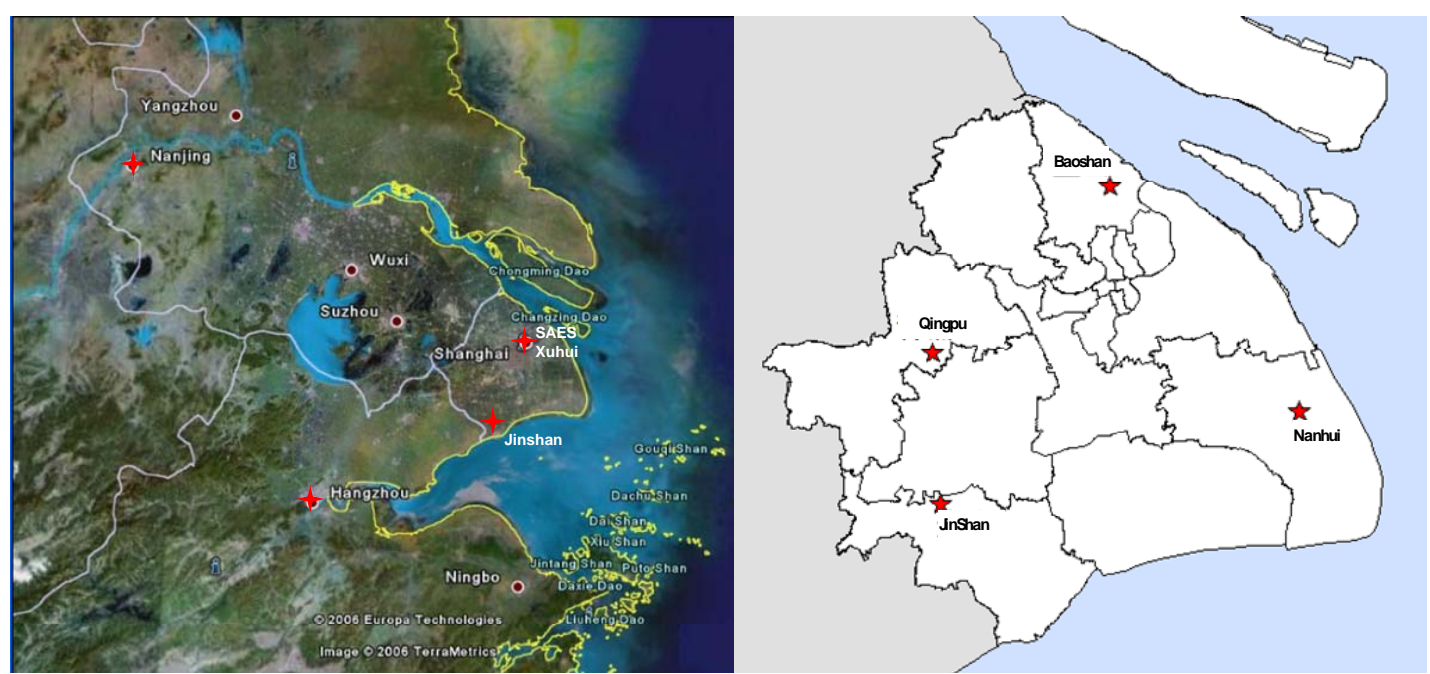

Fig. 5. Locations selected to do $\mathrm{O}_{3}$ process analysis (left) and meteorological stations to do MM5 model evaluation (right) in the YRD.

into gridded meteorological field data as the input to CMAQ. The Carbon Bond 05 chemical mechanism (CB05) (Foley et al., 2010; Yarwood et al., 2005) is used in the CMAQ model (Sarwar et al., 2008).

Geographic Information System (GIS) technology is applied in gridding the YRD regional emission inventory to the model domain. The newly calculated emissions for the YRD in 2007 (Huang et al., 2011) are updated to the year 2010 based on energy consumption and are then inserted into the regional East Asian emission inventory provided by INTEX-B (Fu et al., 2008; Streets et al., 2003a, b; Zhang et al., 2009a). For biogenic VOC emissions, this study uses the natural VOC emission inventory of the GEIA Global Emissions Inventory Activity 1990 (http://geiacenter.org). To help explain the modeling results, Fig. 2 gives the distribution of $\mathrm{NO}_{\mathrm{x}}$ and VOC emissions in the Yangtze River Delta nested in the modeling domain.

\subsection{Model evaluation protocol}

Predicted meteorological parameters including wind speed, wind direction, temperature and humidity are compared with the hourly observational data obtained during August 2010. Performance statistics of MM5 are calculated with application of the Metstat statistical analysis package (Emery et al., 2001).

The simulation of $\mathrm{O}_{3}$ formation during 5-31 August is evaluated against observations made at the supersite in Shanghai Academy of Environmental Sciences (SAES). The 

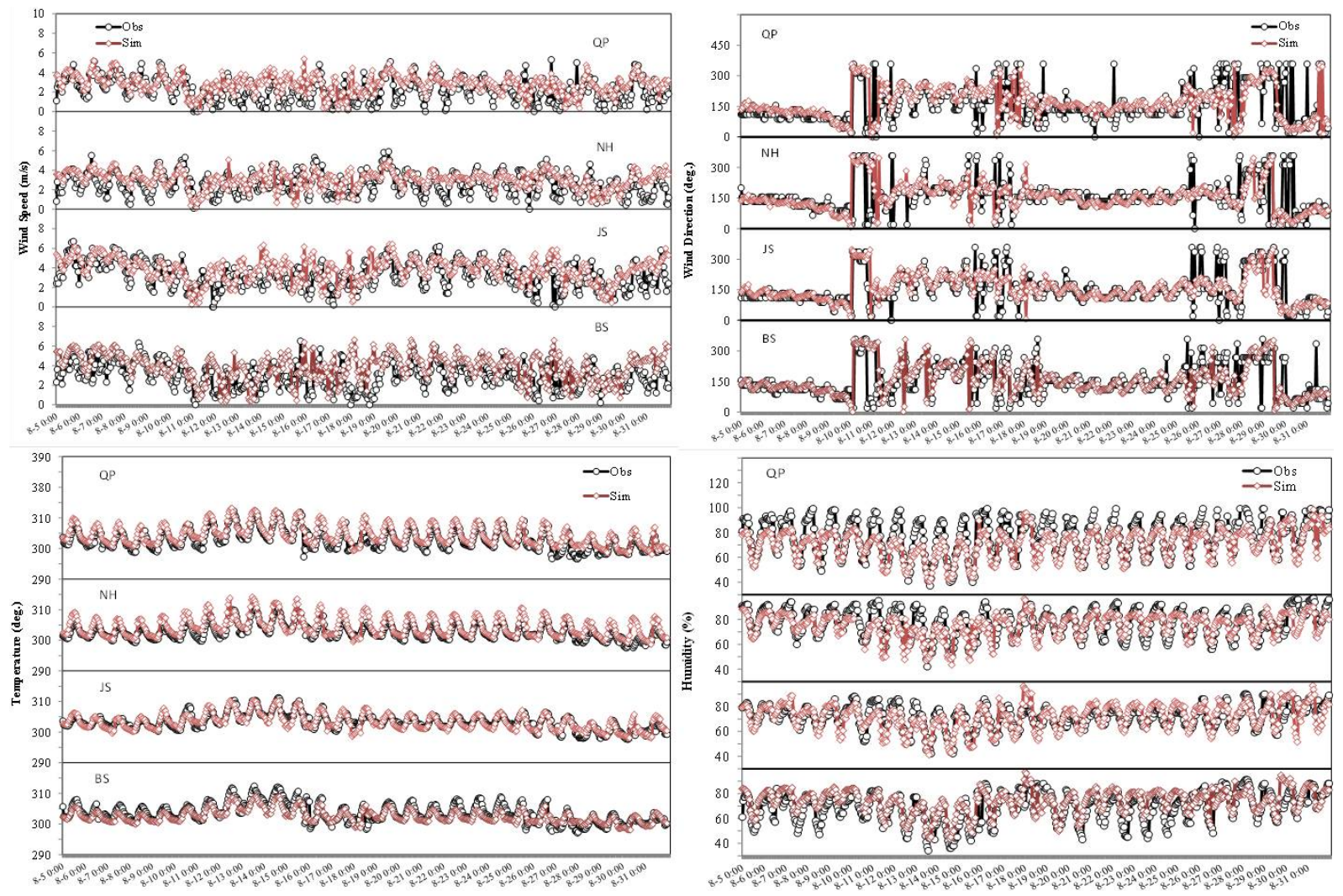

Fig. 6. Time series of simulated surface wind speed, wind direction, temperature and relative humidity compared with observations at four monitoring sites during 5-31 August 2010.
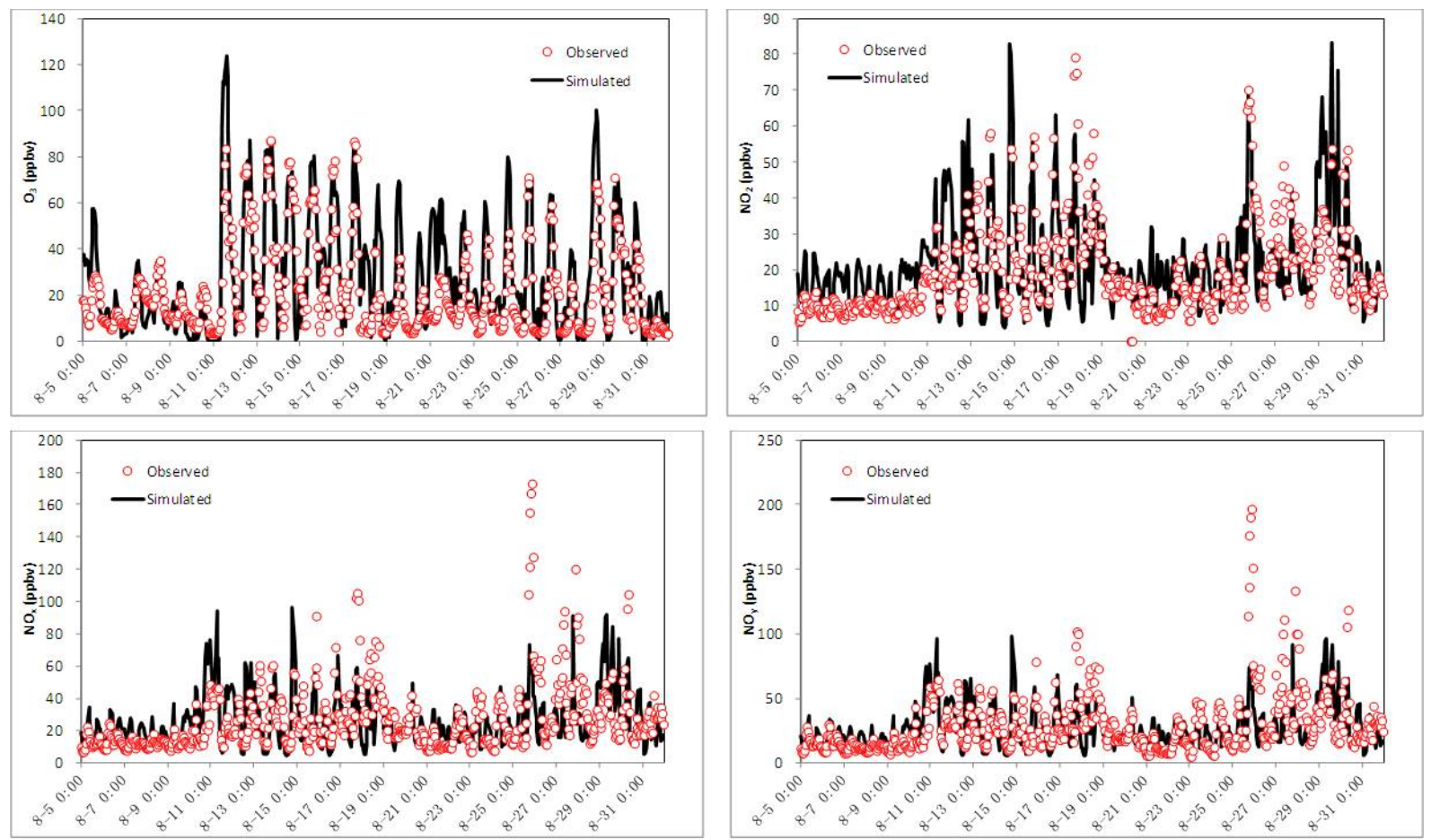

Fig. 7. Time series of simulated surface $\mathrm{O}_{3}, \mathrm{NO}_{2}, \mathrm{NO}_{\mathrm{x}}$ and $\mathrm{NO}_{\mathrm{y}}$ against that observed at SAES monitoring site during 5-31 August 2010. 
measurements are collected simultaneously at the surface site. The levels of $\mathrm{O}_{3}$ and $\mathrm{NO}_{\mathrm{x}}$ were measured by Ecotech commercial instruments EC9811 and EC9841A, respectively.

The model performance is judged by statistical measures, including the normalized mean bias (NMB), normalized mean error (NME), index of agreement (I) and correlation coefficient $(R)$. The NMB, NME and I are calculated by Eqs. (1), (2) and (3):

$$
\begin{gathered}
\mathrm{NMB}=\frac{\sum_{i=1}^{N}\left(P_{i}-O_{i}\right)}{\sum_{i=1}^{N} O_{i}} \times 100 \% \\
\mathrm{NME}=\frac{\sum_{i=1}^{N}\left|P_{i}-O_{i}\right|}{\sum_{i=1}^{N} O_{i}} \\
\mathrm{I}=1-\frac{\sum_{i=1}^{N}\left(p_{i}-o_{i}\right)^{2}}{\sum_{i=1}^{N}\left(\left|p_{i}-\bar{o}\right|+\left|o_{i}-\bar{o}\right|\right)^{2}}
\end{gathered}
$$

Where $p_{i}$ represents the predicted data and $o_{i}$ represents the observational data. $N$ means the number of data pairs. $\bar{o}$ denotes the average observed concentration. The larger the I value, the better the model performs, and a value of 1 indicates perfect agreement between predicted and observed values.

\subsection{Integrated process rate analysis}

Quantifying the contributions of individual processes to model predictions provides a fundamental explanation and shows the relative importance of each process. IPR analysis deals with the effects of all the physical processes and the net effect of chemistry on model predictions. The IPR analysis calculates hourly contributions of horizontal advection and diffusion, vertical advection and diffusion, dry deposition, gas-phase chemistry, cloud processes and aqueous chemistry. The IPR method has been widely applied to regional photochemical pollution studies (Goncalves et al., 2009; Wang et al., 2009a; Xu et al., 2008; Xu and Zhang, 2006; Zhang et al., 2009b, c).

In this paper, 16-17 August is selected for the IPR analysis because the unusually high ozone episode was observed at the observational site of SAES under the special weather conditions.

For the IPR analysis, we first assess the roles of various atmospheric processes in $\mathrm{O}_{3}$ formation at the supersite located in Shanghai Academy of Environmental Sciences, Xuhui District, which represents a typical site in urban Shanghai
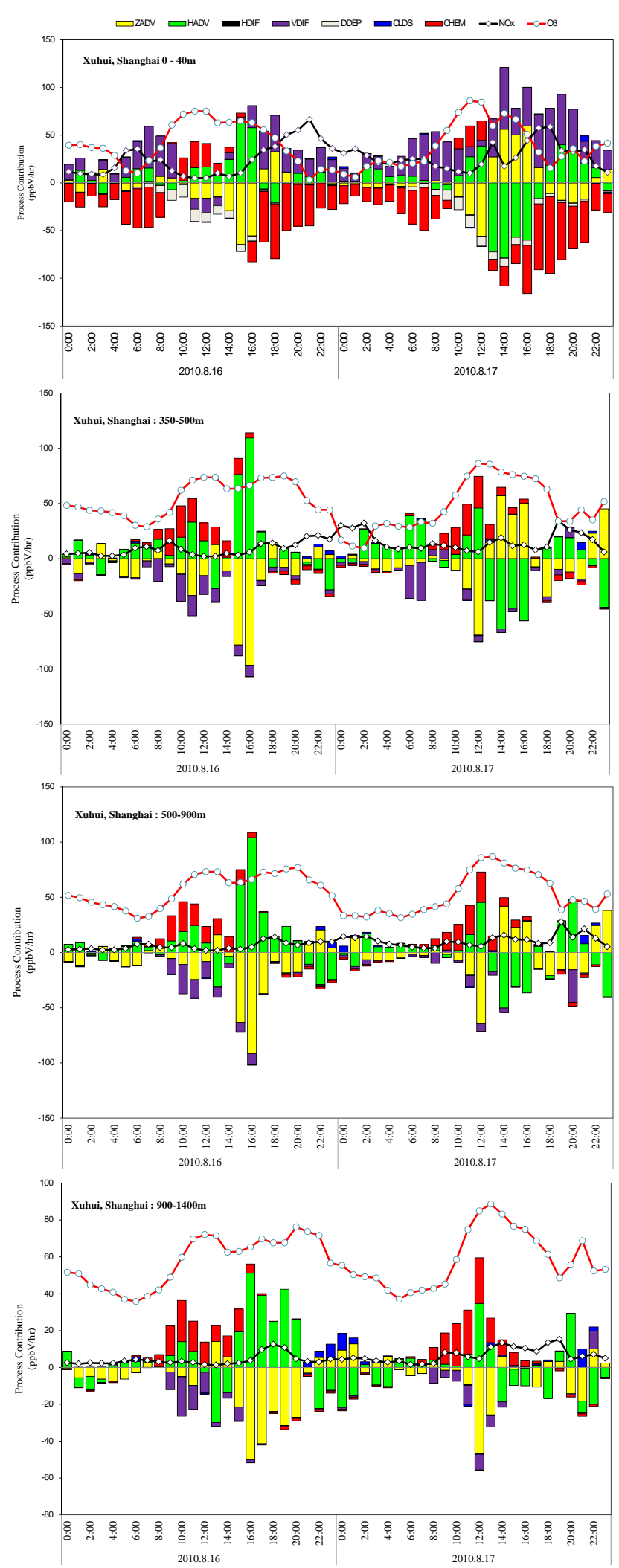

Fig. 8. Atmospheric processes contribution to net $\mathrm{O}_{3}$ density at Xuhui site during 16-17 August 2010. 

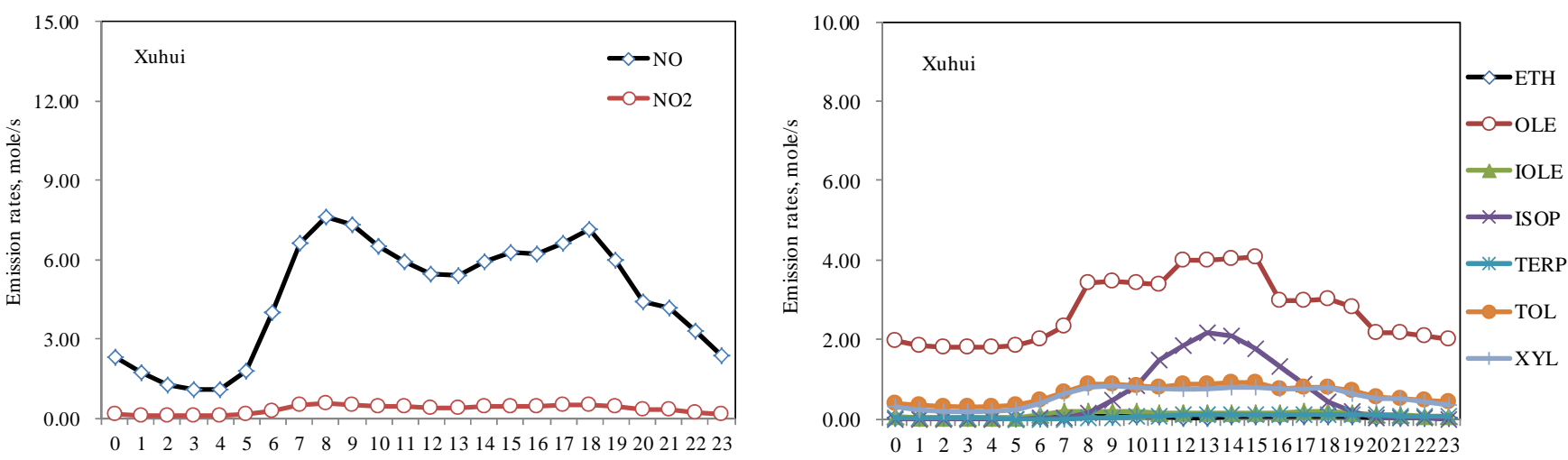

Fig. 9. Emission inputs of $\mathrm{NO}_{\mathrm{x}}$ and main VOC species at Xuhui site.

Table 1. Statistical results between MM5 model and observation data at surface stations in Shanghai.

\begin{tabular}{lllllll}
\hline & & BS & JS & NH & QP & Average \\
\hline Wind Speed & RMSE $\left(\mathrm{m} \mathrm{s}^{-1}\right)$ & 1.89 & 1.50 & 1.18 & 1.32 & 1.47 \\
& Bias $\left(\mathrm{m} \mathrm{s}^{-1}\right)$ & 0.94 & 0.55 & 0.43 & 0.65 & 0.64 \\
& IOA & 0.54 & 0.64 & 0.64 & 0.64 & 0.62 \\
Wind Direction & Gross Error(deg.) & 45.71 & 33.23 & 36.88 & 49.62 & 41.36 \\
& Bias (deg.) & 3.79 & 1.11 & -5.07 & 10.53 & 2.59 \\
Temperature & Gross Error (K) & 1.54 & 1.05 & 1.79 & 1.80 & 1.55 \\
& Bias (K) & -0.91 & -0.037 & 1.58 & 1.49 & 0.53 \\
\multirow{3}{*}{ Relative Humidity } & IOA & 0.86 & 0.93 & 0.84 & 0.89 & 0.88 \\
& Gross Error (\%) & 7.61 & 5.97 & 6.70 & 8.63 & 7.23 \\
& Bias (\%) & 4.40 & -0.11 & -2.45 & -6.06 & -1.06 \\
& IOA & 0.82 & 0.84 & 0.86 & 0.90 & 0.86 \\
\hline
\end{tabular}

with large amounts of traffic emissions of $\mathrm{NO}_{\mathrm{x}}$, and in Jinshan District, a chemical industrial site with high VOC emissions and relatively low $\mathrm{NO}_{\mathrm{x}}$ emissions, which reflects the influences of pollutants transported from upwind areas and local precursor emissions. We then investigate the influences of different processes on the formation and evolution of regional $\mathrm{O}_{3}$ pollution over the YRD region as a whole. The sites we selected include two provincial capital cities, Nanjing and Hangzhou. Nanjing is located in Jiangsu province, northwest of Shanghai, with large amounts of traffic and industrial emissions of $\mathrm{NO}_{\mathrm{x}}$ and VOC. Hangzhou is located in Zhejiang province, southwest of Shanghai. Locations of the sites selected to do $\mathrm{O}_{3}$ process analysis in this study are shown in Fig. 5.

\subsection{Weather condition overview of the episode selected for process analysis}

The period of 16-17 August 2010, was a special summertime situation. During this period, there was a weak trough in the westerly coming from the northwest, and the subtropical high pressure started to move toward the south and became weak. Under this condition, a weak shear line at the convergence zone formed. Shanghai was at the edge of the northwest of the subtropical high pressure system. Both the pressure field and the southwest wind were very weak. It was easy for air pollutants to accumulate, and a high pollution episode occurred. Fig. 3 shows the weather patterns at $850 \mathrm{hpa}$ and 700hpa over eastern Asia at 8:00 a.m., $16 \mathrm{Au}-$ gust 2010. Surface meteorological data show that the average surface temperature was around 30.5 Centigrade, with the maximum temperature of 36.7 Centigrade, occurring at 12:00 LST on 16 August. The average relative humidity was $63.5 \%$, and the wind speed was lower than $1 \mathrm{~m} \mathrm{~s}^{-1}$ during the period.

As shown in Fig. 4, a convergence zone formed over Shanghai and the YRD area, and the surface wind direction changed to southwest on 16 August. The air pollutants accumulated and a high pollution episode occurred. The observed maximum surface hourly $\mathrm{O}_{3}$ concentration in the urban Shanghai area reached $86 \mathrm{ppb}$, which is unusually high in an urban site of the Shanghai region. 
Table 2. Statistical results between CMAQ model and observation data during 5-31 August 2010.

\begin{tabular}{llllll}
\hline Species & Number of data pairs & Correlation coefficient & NMB (\%) & NME (\%) & $\mathrm{I}$ \\
\hline $\mathrm{O}_{3}$ & 672 & 0.78 & $30.22 \%$ & $55.83 \%$ & 0.91 \\
$\mathrm{NO}_{2}$ & 672 & 0.53 & $13.78 \%$ & $48.41 \%$ & 0.91 \\
$\mathrm{NO}_{\mathrm{x}}$ & 669 & 0.42 & $-2.67 \%$ & $50.51 \%$ & 0.63 \\
$\mathrm{NO}_{\mathrm{y}}$ & 669 & 0.45 & $-5.10 \%$ & $48.55 \%$ & 0.64 \\
\hline
\end{tabular}

Table 3. Comparisons between the modeled hourly, max and min data against observations of surface $\mathrm{O}_{3}, \mathrm{NO}_{2}, \mathrm{NO}_{\mathrm{x}}$ and $\mathrm{NO}_{\mathrm{y}}$ during August 5-31, 2010.

\begin{tabular}{lllllllll}
\hline & \multicolumn{3}{c}{$\mathrm{O}_{3}$} & \multicolumn{3}{c}{$\mathrm{NO}_{2}$} & \multicolumn{3}{c}{$\mathrm{NO}_{\mathrm{x}}$} & \multicolumn{2}{c}{$\mathrm{NO}_{\mathrm{y}}$} \\
\hline & Observation & Model & Observation & Model & Observation & Model & Observation & Model \\
Hourly & 42.92 & 55.90 & 38.56 & 21.97 & 26.82 & 25.98 & 28.78 & 27.19 \\
Max & 87.00 & 123.46 & 79.00 & 83.31 & 172.70 & 96.62 & 196.39 & 98.41 \\
Min & 3.20 & 0.00 & 0.00 & 3.93 & 6.70 & 4.54 & 5.43 & 1.27 \\
\hline
\end{tabular}

\section{Results and discussion}

\subsection{Evaluation of model performance}

Table 1 shows comparisons between observed and modeled meteorological parameters including surface temperature, wind speed, wind direction and relative humidity during the period of 5-31 August 2010 at four surface stations in Shanghai, namely Baoshan (BS), Jinshan (JS), Nanhui (NH) and Qingpu (QP), shown in Fig. 5. The average bias of wind speed, wind direction, temperature and humidity are 0.64 , $2.59,0.53$ and -1.06 respectively. Figure 6 shows the hourly comparisons of the meteorological parameters, which indicates that MM5 can reflect the variation trends of the major meteorological conditions. The selected parameters adopted in MM5 can be used in the pollutant concentration simulation.

Figure 7 shows the comparisons between model results and observational data for $\mathrm{O}_{3}, \mathrm{NO}_{2}, \mathrm{NO}_{\mathrm{x}}$ and $\mathrm{NO}_{\mathrm{y}}$ hourly concentrations at SAES during 5-31 August 2010. Results show that CMAQ can reproduce the variation trends of the $\mathrm{O}_{3}$, with a correlation coefficient of 0.78 , NMB of $30.2 \%$, NME of $55.8 \%$, and I of 0.91 , comparable to the performance of other CMAQ applications (Goncalves et al., 2009; Shen et al., 2011). The model also reproduces the daily change of $\mathrm{O}_{3}$ concentration. The $\mathrm{O}_{3}$ concentration reaches its maximum at around noon time and gradually decreases to its minimum after midnight. Comparisons of precursor concentrations including $\mathrm{NO}_{2}, \mathrm{NO}_{\mathrm{x}}$ and $\mathrm{NO}_{\mathrm{y}}$ at the monitoring site further demonstrate that the $\mathrm{O}_{3}$ formation is captured reasonably well over the domain and throughout the period. The indexes of agreement for $\mathrm{NO}_{2}, \mathrm{NO}_{\mathrm{x}}$ and $\mathrm{NO}_{\mathrm{y}}$ are $0.91,0.63$ and 0.64 respectively, as shown in Table 2. The index of agreement for $\mathrm{O}_{3}$ and $\mathrm{NO}_{2}$ shows that the model captures well the diurnal variations of the pollutants. However, the index of agreement decreases from $\mathrm{NO}_{2}$ to $\mathrm{NO}_{\mathrm{x}}$. As shown in both Table 2 and Fig. 7, CMAQ overpredicts $\mathrm{NO}_{2}$, while slightly underpredicts $\mathrm{NO}_{\mathrm{x}}$. Therefore, CMAQ tends to under-predict NO mixing ratios, indicating that the nonlinearity of chemical reactions and heterogeneity associated with precursor emissions has impact on model predictions. The bias of $\mathrm{O}_{3}, \mathrm{NO}_{2}$ and $\mathrm{NO}_{\mathrm{x}}$ can be attributed to the uncertainties in emissions, meteorology, and deviation of observations. The average biases of wind speed, wind direction, temperature and humidity are $0.65,2.5,0.13$ and -0.81 respectively. These model biases may affect process analysis results to some extent. For example, under-prediction of NO may cause some of the under-predictions of the negative contribution to $\mathrm{O}_{3}$ by photochemistry. The over-prediction of wind speed may also cause the over-prediction of $\mathrm{O}_{3}$ increase due to horizontal advection. And the error of simulated temperature may also affect the photochemical of $\mathrm{O}_{3}$. Nevertheless, the model performance shows that both the MM5 and CMAQ performance are acceptable compared to related studies (Liu et al., 2010; Wang et al., 2010; Zhang et al., 2006). Thus, the modeling system can be used to do process analysis to provide valuable insights into the governing processes that control $\mathrm{O}_{3}$ concentrations.

\subsection{Process analysis of ozone formation}

\subsubsection{Urban area of Shanghai}

The contributions of different atmospheric processes to the evolution of $\mathrm{O}_{3}$ in the urban Shanghai area (Xuhui) from 16 to 17 August 2010 at different layers are shown in Fig. 8. As shown in the figure, in the first layer $(0-40 \mathrm{~m})$ of the urban Shanghai area, the major contributors to high $\mathrm{O}_{3}$ concentrations in daytime include vertical diffusion (VDIF), vertical advection (ZADV) and horizontal advection (HADV), while gas-phase chemistry (CHEM) exhibited a significant consumption of $\mathrm{O}_{3}$ during most times of the day except 

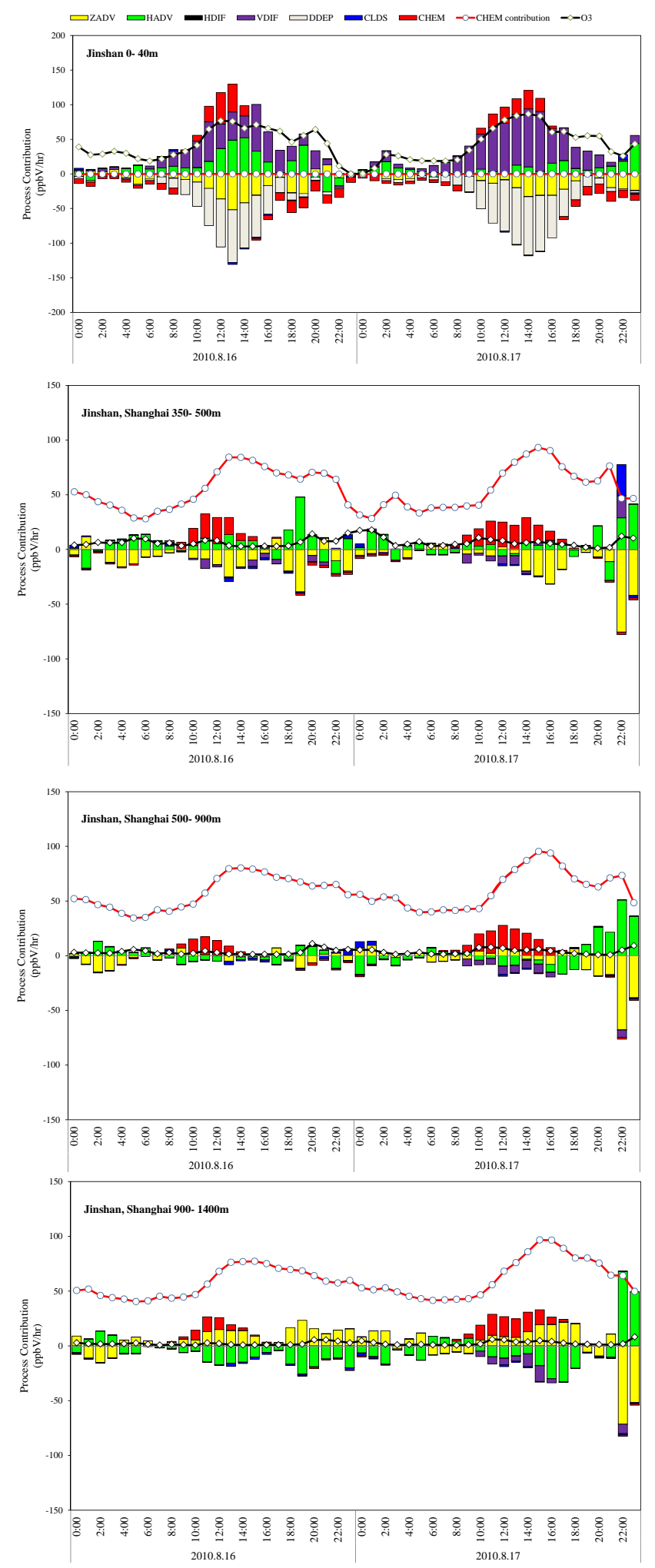

Fig. 10. Atmospheric processes contribution to net $\mathrm{O}_{3}$ density at Jinshan site during 16-17 August 2010.
10:00-16:00 LST, due to the high emissions of $\mathrm{NO}_{\mathrm{x}}$ from vehicle exhausts. During the simulation period, the average positive contributions of vertical diffusion and horizontal transport are $24.7 \mathrm{ppbh}^{-1}, 3.6 \mathrm{ppbh}^{-1}$, accounting for $27.6 \%$ and $6.6 \%$ respectively. Photochemistry, dry deposition (DDEP) and vertical advective transport are the three major sinks of $\mathrm{O}_{3}$. The average contributions of CHEM, DDEP and ZADV to $\mathrm{O}_{3}$ change are $-21.9,-4.3$ and $-2.1 \mathrm{ppbh}^{-1}$, accounting for $-25.3 \%,-5.0 \%$ and $-3.7 \%$ respectively.

During the buildup of daytime maximum $\mathrm{O}_{3}$ from 10:00 to 12:00 LST on both 16 and 17 August, gas-phase chemistry also plays an important role in the formation of high $\mathrm{O}_{3}$ concentrations. The maximum $\mathrm{O}_{3}$ concentration approached $75.3 \mathrm{ppb}$ and $86.2 \mathrm{ppb}$ at 12:00 and 11:00 LST on 16 and 17 August, respectively. In the early morning hours of the episode, $\mathrm{O}_{3}$ levels produced by local photochemistry were rarely zero. After 10:00 LST, the photochemistry contribution to $\mathrm{O}_{3}$ formation became obvious, with the highest positive concentration of $27 \mathrm{ppbh}^{-1}$ and $21.7 \mathrm{ppbh}^{-1}$ to the hourly $\mathrm{O}_{3}$ concentration, accounting for $58 \%$ and $20 \%$ on 16 and 17 August, respectively. The $\mathrm{O}_{3}$ maximum concentrations during the 16 and 17 August occur at 11:00 LST on 17 August. At this time, the horizontal advective transport into the area constitutes the major positive contribution to net $\mathrm{O}_{3}$, with the ozone formation rate of $27.4 \mathrm{ppbh}^{-1}$, accounting for $25.6 \%$ of net surface $\mathrm{O}_{3}$ production; photochemistry is the second largest contributor, with the ozone formation rate of $21.7 \mathrm{ppbh}^{-1}$ and $20.3 \%$ of positive contribution. There is also a significant vertical advective transport from the upper layer, with $10.7 \mathrm{ppbh}^{-1}$. Later on, until 17:00 LST, the horizontal advective flows remove $\mathrm{O}_{3}$ from this area, with $-56.5 \mathrm{ppb} \mathrm{h}^{-1}$ on average, due to the transport of the pollution plume.

During the IPR analysis period, the $\mathrm{O}_{3}$ increase by both horizontal transport and photochemistry was stronger at 300 $1500 \mathrm{~m}$ height than in the surface layer, causing a strong vertical $\mathrm{O}_{3}$ transport from upper levels to the surface layer. This indicates that the strong vertical $\mathrm{O}_{3}$ import at surface layer is initiated by the urban plume arrival. At $900-1400 \mathrm{~m}$ height, the cloud processes contribute positively to the $\mathrm{O}_{3}$ via convective mixing process that brings high $\mathrm{O}_{3}$ aloft to lower atmosphere. On 17 August, high $\mathrm{O}_{3}$ input by transport occurred later in the afternoon, arising from well-developed photochemistry in the urban plume, thereby further enhancing the $\mathrm{O}_{3}$ concentrations in the urban Shanghai area and leading to another high $\mathrm{O}_{3}$ episode, approaching $86 \mathrm{ppb}$.

As discussed above, gas-phase chemistry in the surface layer could either increase or reduce $\mathrm{O}_{3}$ concentrations, depending on locations and times. Figure 9 shows the local emission inputs of $\mathrm{NO}, \mathrm{NO}_{2}$ and seven major VOC species including ethane (ETH), terminal olefin carbon bond (OLE), internal olefin carbon bond (IOLE), isoprene (ISOP), terpene (TERP), toluene and other monoalkyl aromatics (TOL) and xylene and other polyalkyl aromatics (XYL) at the Xuhui 

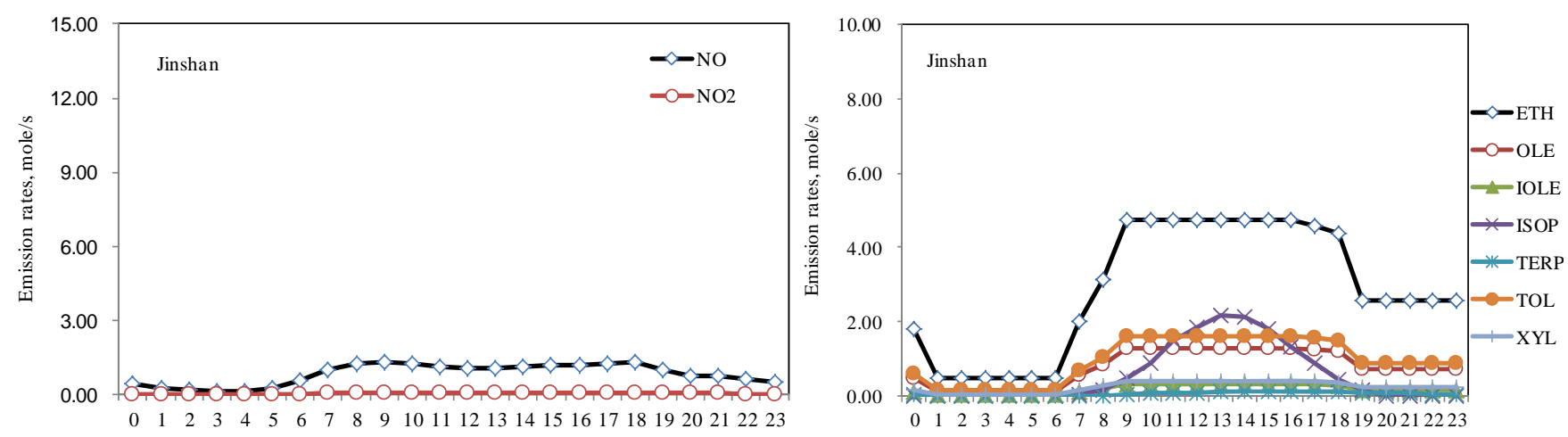

Fig. 11. Emission inputs of $\mathrm{NO}_{\mathrm{x}}$ and main VOC species at Jinshan site.

site. These figures show that the NO emissions in the urban Shanghai area are more significant than the VOCs emissions. Thus, in the daytime, especially during 10:00-16:00 LST, when both the precursor emissions and the solar radiation are high, the gas-phase chemistry plays a positive effect on $\mathrm{O}_{3}$ production, while after sunset, the high emissions of $\mathrm{NO}$ quickly titrate $\mathrm{O}_{3}$, causing the destruction of $\mathrm{O}_{3}$.

\subsubsection{Suburban and industrial area of Shanghai}

The Jinshan District is located in the southwest of the urban Shanghai area. It belongs to an oil and chemical industrial region. A big petrochemical enterprise, Shanghai Jinshan Petrochemical Company is located in this region. Compared to the urban Shanghai area, which contains high $\mathrm{NO}_{\mathrm{x}}$ emissions from motor vehicles, the emissions of volatile organic compounds (VOC) are much more significant while the $\mathrm{NO}_{\mathrm{x}}$ emissions are not so much as those in the urban area. As shown in Fig. 10, the major processes controlling the surface ozone production in the JS site during the daytime on both days include photochemical reaction, vertical diffusion and horizontal advective transport, while dry deposition and vertical advective transport are the most significant sinks of $\mathrm{O}_{3}$. During the simulation period, the average positive contributions of vertical diffusion and horizontal transport are $25.8 \mathrm{ppbh}^{-1}, 10.3 \mathrm{ppb} \mathrm{h}^{-1}$, accounting for $25.9 \%$ and $11.3 \%$ of net $\mathrm{O}_{3}$ change, respectively. The average $\mathrm{O}_{3}$ production rates contributed by dry deposition and vertical advective transport are -24.1 , and $-11.9 \mathrm{ppbh}^{-1}$, accounting for $-20.5 \%$ and $-11.2 \%$ of net $\mathrm{O}_{3}$ change, respectively.

The $\mathrm{O}_{3}$ production rates from chemistry during 10:0014:00 LST on 16-17 August 2010 are between 8.2$45.4 \mathrm{ppbh}^{-1}$. The maximum ozone production rates from photochemical reaction were 45.4 and $23.3 \mathrm{ppb} \mathrm{h}^{-1}$, occurring at 12:00 on 16 August and 14:00 on 17 August, with the contribution of $20.4 \%$ and $12.9 \%$, respectively. The process contributions to net surface $\mathrm{O}_{3}$ concentrations assessed at the JS site during this period indicate that net transport (ZADV + HADV + HDIF + VDIF) accounts for $26.3 \%$, chemical re- action for $-11.1 \%$, dry deposition for $-20.5 \%$, clouds processes and aqueous chemistry for $0.7 \%$.

The daily changes of $\mathrm{O}_{3}$ concentrations are most significant in the surface layers; however, the diurnal change becomes less with vertical height. At the 900-1400 m height, the ozone concentrations remain around $50 \mathrm{ppb}$.

Compared with the urban Shanghai area, the VOC emissions at the Jinshan site are more significant than the NO emissions, showing that the gas-phase chemistry in this region mainly plays a positive effect on $\mathrm{O}_{3}$ production, while the NO titration to $\mathrm{O}_{3}$ is weaker.

\subsubsection{Nanjing, the capital city of Jiangsu province}

The surface $\mathrm{O}_{3}$ concentrations in Nanjing, the capital city of Jiangsu province, have been modeled and the IPR analysis was applied into the process contribution calculation. As shown in Fig.12, the major processes controlling the surface ozone production at the Nanjing site during the daytime on both days include vertical diffusion and horizontal transport, while photochemical reaction, vertical advective transport and dry deposition are the most significant sinks of $\mathrm{O}_{3}$. During the simulation period, the average $\mathrm{O}_{3}$ production rates contributed by vertical diffusion and horizontal transport are $25.3 \mathrm{ppbh}^{-1}, 15.3 \mathrm{ppbh}^{-1}$, accounting for $25.8 \%$ and $18.5 \%$ of net $\mathrm{O}_{3}$ change, respectively. The average contributions of photochemistry, vertical advective transport and dry deposition to $\mathrm{O}_{3}$ change are $-30.6,-6.2$ and $-3.7 \mathrm{ppb} \mathrm{h}^{-1}$, accounting for $-31.8 \%,-7.3 \%$ and $-4.7 \%$, respectively. The maximum surface $\mathrm{O}_{3}$ concentration was $88.7 \mathrm{ppb}$, occurring at 12:00 LST on 16 August 2010. At this time, the $\mathrm{O}_{3}$ production rate from chemistry is $46.7 \mathrm{ppb} \mathrm{h}^{-1}$, accounting for $59.4 \%$ of the net $\mathrm{O}_{3}$ concentration change. The process contributions to net surface $\mathrm{O}_{3}$ concentrations assessed at the Nanjing site during this period indicate that net transport accounts for $9 \%$ and chemical reaction for $-32 \%$.

However, if we look at the $\mathrm{O}_{3}$ concentration changes at 350-500 $\mathrm{m}$ and 500-900 $\mathrm{m}$, we can see that during the time period of 10:00-15:00 LST, photochemistry plays the most 

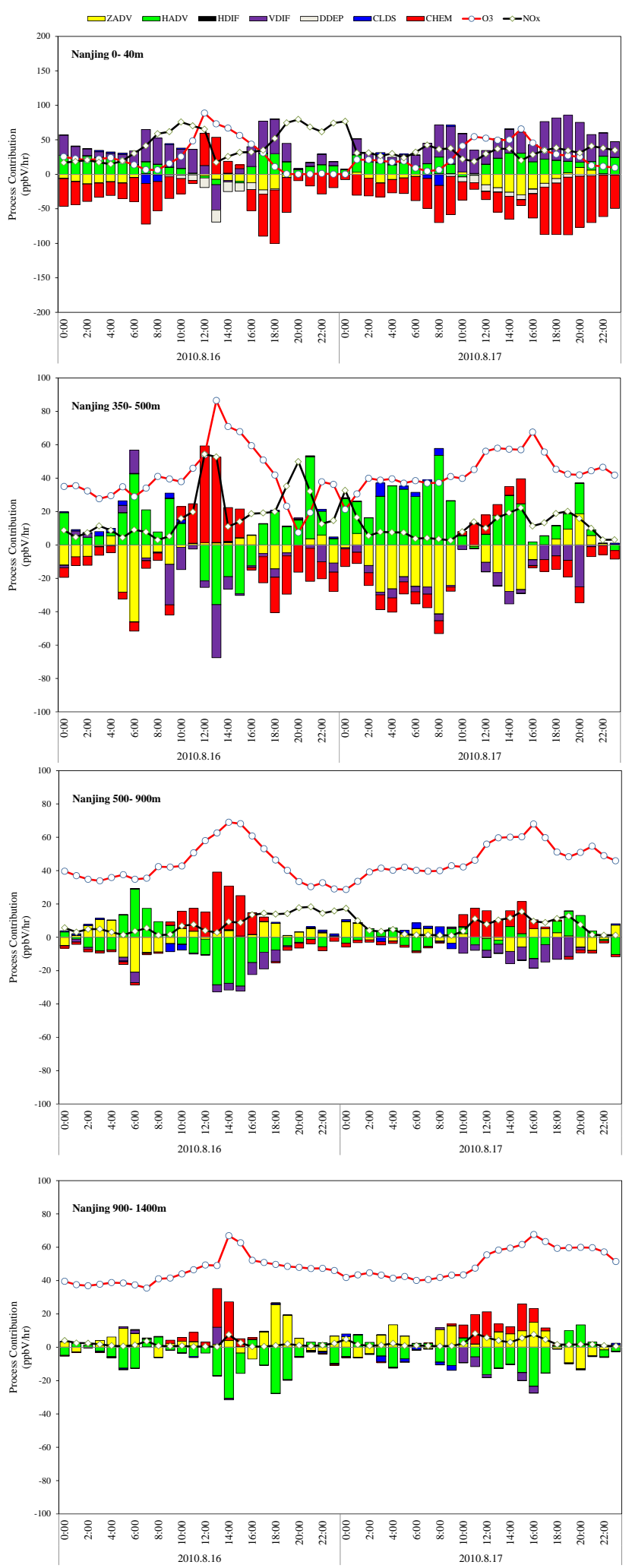

Fig. 12. Atmospheric processes contribution to net $\mathrm{O}_{3}$ density at Nanjing site during 16-17 August 2010. important role in net $\mathrm{O}_{3}$ production. The highest positive contributions from gas-phase chemistry to net $\mathrm{O}_{3}$ production at $350-500 \mathrm{~m}$ and $500-900 \mathrm{~m}$ reached $87.3 \%$ and $68.6 \%$, respectively, causing strong vertical $\mathrm{O}_{3}$ transport from the upper level to the surface layer. The cloud processes contribute slightly to the $\mathrm{O}_{3}$ increase at the height $350-500 \mathrm{~m}$ and 500 $900 \mathrm{~m}$, due to convective clouds transporting pollutants vertically.

Figure 10 shows the emission inputs of $\mathrm{NO}_{\mathrm{x}}$ and main VOC species at the Nanjing site. As shown in the figure, the $\mathrm{NO}_{\mathrm{x}}$ emissions from both traffic and industries are high, and the VOC emissions, especially the terminal olefin carbon bond (OLE) emissions, are also quite high due to both vehicles and the petrochemical companies. Therefore, the $\mathrm{O}_{3}$ precursor emissions at the Nanjing site are much higher than at the other sites, so the positive contribution to $\mathrm{O}_{3}$ from gasphase chemistry is high, and the highest $\mathrm{O}_{3}$ mixing ratio at the Nanjing site reached $86.5 \mathrm{ppb}$.

\subsubsection{Hangzhou, the capital city of Zhejiang province}

Although during 16-17 August 2010, Shanghai and Nanjing experienced high $\mathrm{O}_{3}$ concentrations, a similar situation did not occur in Hangzhou. Modeling results show that the highest $\mathrm{O}_{3}$ concentration at Hangzhou during this period was only 59.0 ppb, occurring at 15:00 LST on 17 August, 2010. The $\mathrm{O}_{3}$ concentrations in layers $6(350-500 \mathrm{~m})$ and $8(500-$ $900 \mathrm{~m}$ ) are generally higher than in the surface layer, which is around $50 \mathrm{ppb}$ during the whole simulation period. As shown in Fig. 14, the major process controlling the surface ozone production at the Hangzhou site during the daytime on both days is vertical diffusion, while dry deposition is the most important sink of $\mathrm{O}_{3}$. During the simulation period, the average positive contribution of vertical diffusion is $21.4 \mathrm{ppb} \mathrm{h}^{-1}$, accounting for $28.9 \%$. During the buildup of the daytime maximum $\mathrm{O}_{3}$ concentration from 10:00 to 14:00 LST on both 16 and 17 August, gas-phase chemistry also plays an important role in the formation of net surface $\mathrm{O}_{3}$. The average positive contributions to $\mathrm{O}_{3}$ are 12.6 and $7.0 \mathrm{ppbh}^{-1}$, accounting for $10.7 \%$ and $6.2 \%$ during this time period on 16 and 17 August 2010 respectively. The process contributions to net surface $\mathrm{O}_{3}$ concentrations assessed at the Hangzhou site during this period indicate that net transport accounts for $34 \%$, chemical reaction for $-9 \%$, dry deposition for $-26 \%$, clouds processes and aqueous chemistry for $-1 \%$.

Figure 15 shows the emission inputs of $\mathrm{NO}_{\mathrm{x}}$ and the main VOC species at the Hangzhou site. It can be seen that the NO emissions at the Hangzhou site are much lower than in urban Shanghai and Nanjing, similar to those at the Jinshan site. However, the VOC emissions are lower than those in Jinshan. Thus, the $\mathrm{O}_{3}$ destruction due to NO titration is not very significant. However, since the $\mathrm{O}_{3}$ precursor emissions are the lowest among all the sites analyzed, the highest $\mathrm{O}_{3}$ concentration at the Hangzhou site was only $59 \mathrm{ppb}$. 

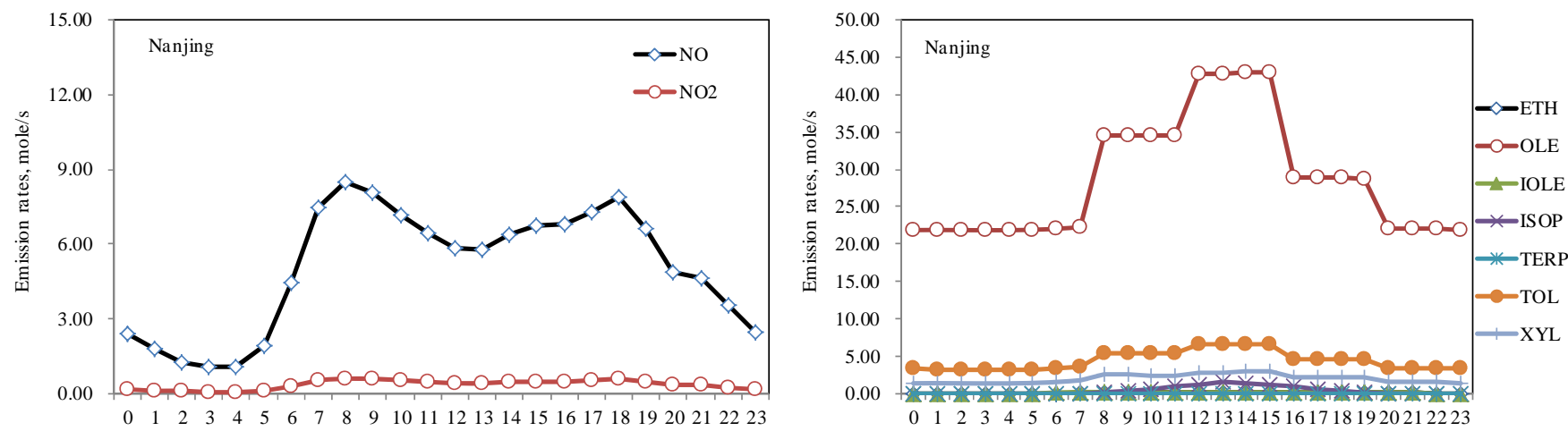

Fig. 13. Emission inputs of $\mathrm{NO}_{\mathrm{x}}$ and main VOC species at Nanjing site.

\subsection{Regional ozone transport}

Figure 16 shows the time series of meteorological conditions and $\mathrm{O}_{3}$ and $\mathrm{NO}_{\mathrm{x}}$ mass concentrations observed at the site of SAES during the high $\mathrm{O}_{3}$ pollution episode on 16-17 August 2010. During the pollution episode, the $\mathrm{NO}_{\mathrm{x}}, \mathrm{O}_{3}$ and $\mathrm{O}_{\mathrm{x}}\left(\mathrm{NO}_{2}+\mathrm{O}_{3}\right)$ continued to increase. Daily average concentrations of $\mathrm{NO}_{2}$ and $\mathrm{O}_{\mathrm{x}}$ were $23.4 \mathrm{ppb}$ and $57.5 \mathrm{ppb}$ on 16 August, and increased to $35.0 \mathrm{ppb}$ and $66.5 \mathrm{ppb}$ on $17 \mathrm{Au}-$ gust 2010, respectively. The maximum hourly concentration of $\mathrm{O}_{3}$ increased from $75.1 \mathrm{ppb}$ on 16 August to $86.5 \mathrm{ppb}$ on 17 August, 2010. During the period, the air temperature was around $30^{\circ}$, with the highest temperature of $36.7^{\circ}$ at $12: 00$ on 16 August and $34.7^{\circ}$ at 12:00 on 17 August, 2010. The highest solar radiation levels were 786 and $571 \mathrm{~W} \mathrm{~m}^{-2}$ on 16 and 17 August, respectively. Under the high atmospheric oxidation conditions, the $\mathrm{NO}$ was rapidly oxidized to $\mathrm{NO}_{2}$, which was subsequently converted to $\mathrm{O}_{3}$ by photolytic destruction.

The $\mathrm{O}_{3}$ concentrations in most urban cities during the night time (00:00-06:00) are very low, because the high NO emissions in the urban area gradually titrate ozone, which causes the ozone concentration to decrease. On August 16, 2010, the $\mathrm{O}_{3}$ concentration in the Yangtze River Delta, such as the cities of Suzhou, Hangzhou and Ningbo, started to increase at 08:00 as shown in Fig. 17. Under the southwest wind direction, this ozone started to diffuse to Shanghai and the surrounding area. From 10:00 on 16 August, the $\mathrm{O}_{3}$ production from photochemistry in major cities like Hangzhou, Ningbo, Shanghai and Suzhou is high. The maximum ozone production rates from photochemical reaction reached $45.4 \mathrm{ppb} \mathrm{h}^{-1}$, occurring at 12:00 on 16 August, with the contribution of $20.4 \%$ to the total $\mathrm{O}_{3}$. Later on, the $\mathrm{O}_{3}$ is transported to the ocean under the westerly wind, and then flows back to North Shanghai and the southern part of Jiangsu province due to the northeast wind off the sea. After sunset, the $\mathrm{O}_{3}$ concentrations started to decrease.

On the next day, $\mathrm{O}_{3}$ was produced from chemical reactions in the cities of Shanghai, Hangzhou, Suzhou, and Wuxi from 08:00 on 17 August 2010. The $\mathrm{O}_{3}$ transported during
06:00-12:00 is mainly surrounding the Shanghai area, since the wind speed is relatively low, as shown from both Fig. 16 and Fig. 17. However, after 12:00 LST, 17 August 2010, the wind speed gradually became bigger, and the major wind direction was southeast, as shown in Figs. 16 and 17. Later on, it spreads to the northwest part of the region, including Nanjing, under the prevailing wind.

\section{Conclusions}

The Integrated Process Rate implemented in the CMAQ model was applied to obtain quantitative information about atmospheric processes affecting the ozone concentration in typical cities located in the Yangtze River Delta area, including Shanghai, Nanjing and Hangzhou. A representative summertime photochemical pollution episode (16-17 August 2010) was selected. Applying the Integrated Process Rate tool to the first vertical layer simulated provides information about the surface concentration of pollutants estimated by the model. In order to perform a deeper study of the contributions of the main atmospheric processes leading to the levels of these pollutants, the vertical ozone production in layer $1(0-40 \mathrm{~m})$, layer $7(350-500 \mathrm{~m})$, layer $8(500-$ $900 \mathrm{~m}$ ) and layer $10(1400-2000 \mathrm{~m})$ have been examined.

Process analysis indicates that the maximum concentration of photochemical pollutants occur due to transport phenomena, including vertical transport and horizontal transport. The gas-phase chemistry producing $\mathrm{O}_{3}$ mainly occurs at the height of 300-1500m, causing strong vertical $\mathrm{O}_{3}$ transportation from upper levels to the surface layer. In the downwind area, the high surface $\mathrm{O}_{3}$ levels are not produced in situ, but come from horizontally advected flows during the morning and gas-phase chemical contributions occurring aloft. The urban Shanghai domain behavior differs slightly: the horizontal advection is also the main contributor to $\mathrm{O}_{3}$ surface concentrations, but the chemical formation takes place in the whole vertical column below the PBL.

The gas-phase chemistry is an important sink for $\mathrm{O}_{3}$ in the lowest layer, coupled with vertical diffusion flows and dry 

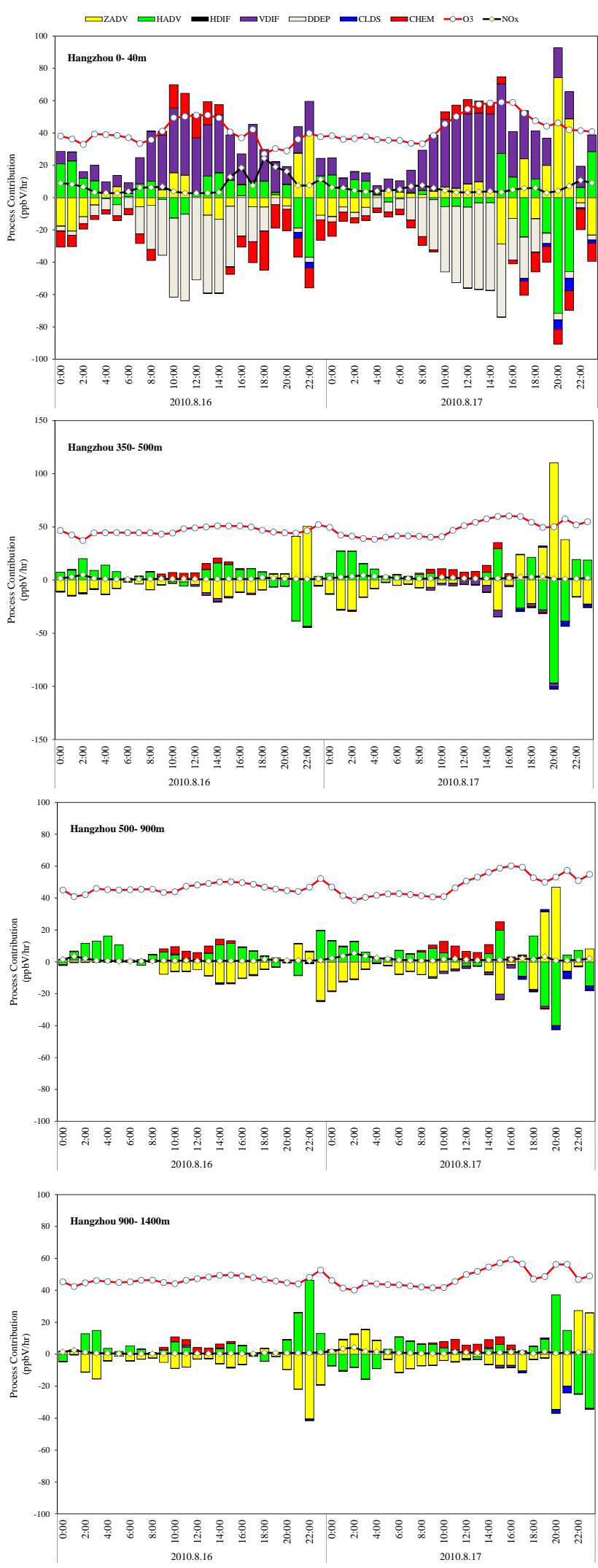

Fig. 14. Atmospheric processes contribution to net $\mathrm{O}_{3}$ density at Hangzhou site during 16-17 August 2010. deposition. The diffusive process contributions to net $\mathrm{O}_{3}$ concentrations under the PBL are relatively low, and in particular the horizontal diffusion is negligible compared to other atmospheric processes. Vertical diffusion compensates for the loss of $\mathrm{O}_{3}$ in the surface layers due to $\mathrm{NO}$ titration, contributing positively to net $\mathrm{O}_{3}$ concentrations in urban areas. The $\mathrm{O}_{3}$ peaks at surface level are higher in the suburban industrial region (Jinshan), mainly due to the much simpler transport pattern compared to the downtown region, together with the more significant photochemistry. The dry deposition is the main sink of $\mathrm{O}_{3}$ at the surface layer. Cloud processes may contribute slightly to the increase of $\mathrm{O}_{3}$ due to convective clouds transporting pollutants vertically, or to the decrease of $\mathrm{O}_{3}$ due to scavenging or attenuating solar radiation below the cloud base which has a significant impact on the photolysis reactions. The wet deposition and heterogeneous chemistry contributions are negligible during the whole episode, characterized by high solar radiation and no precipitation or cloudiness. In this study, it was not possible to compare the vertical simulation results with measurements, because the vertical $\mathrm{O}_{3}$ distribution has not been measured in the YRD. If such measurements do become available in the future, we plan to incorporate them in a future study.

As shown by the modeling results, the $\mathrm{O}_{3}$ pollution characteristics among the different cities in the YRD region have both similarities and differences. During the buildup period (usually from 08:00 in the morning after sunrise), the $\mathrm{O}_{3}$ starts to appear in the city regions like Shanghai, Hangzhou, Ningbo and Nanjing and is then transported to the surrounding areas under the prevailing wind conditions. On both days, the $\mathrm{O}_{3}$ production from photochemical reactions in Shanghai and the surrounding area is very obvious, due to the high emission intensity in the large city; this ozone is then transported out to sea by the westerly wind flow, and later diffuses to rural areas like Chongming island, Wuxi and even to Nanjing. In the urban cities like Xuhui of Shanghai, and Hangzhou, the emissions of $\mathrm{NO}_{\mathrm{x}}$ from vehicles are more significant than the $\mathrm{VOC}$, and thus the $\mathrm{O}_{3}$ concentrations are more sensitive to VOC ( $\mathrm{Li}$ et al., 2011b), while in the oil and chemicals industrial region and the rural areas where the $\mathrm{NO}_{\mathrm{x}}$ emissions are not so significant, the $\mathrm{O}_{3}$ concentrations are likely to be $\mathrm{NO}_{\mathrm{x}}$-sensitive. In the $\mathrm{NO}_{\mathrm{x}}$-sensitive areas like Jinshan district, the ozone production rates from photochemical reaction are higher than the urban area, together with the significant horizontal transport, the $\mathrm{O}_{3}$ concentration is higher than in the urban area which is a VOC limited region. Both the precursor emissions of $\mathrm{NO}_{\mathrm{x}}$ and VOC at the Nanjing site are very high, causing the $\mathrm{O}_{3}$ concentration to be the highest, while those at the Hangzhou site are lowest, and the $\mathrm{O}_{3}$ concentrations are not so high as those at other sites during the simulation period. The $\mathrm{O}_{3}$ concentrations start to decrease in the cities after sunset, due to titration of the NO emissions, but ozone can still be transported and maintain a high concentration in rural areas and even regions outside the YRD region, where the $\mathrm{NO}$ emissions are very small. 

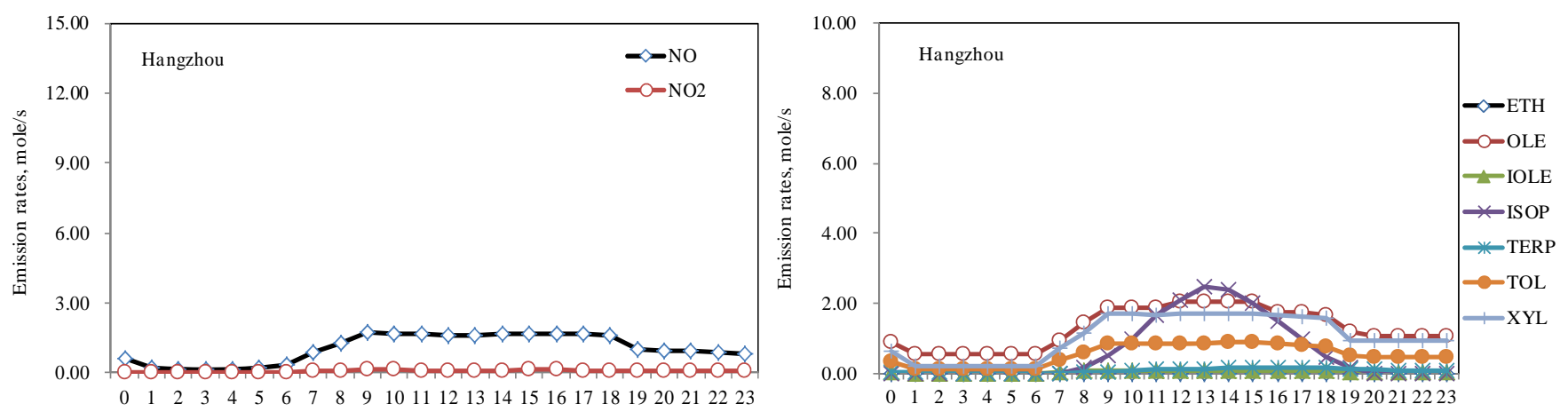

Fig. 15. Emission inputs of $\mathrm{NO}_{\mathrm{x}}$ and main VOC species at the Hangzhou site.

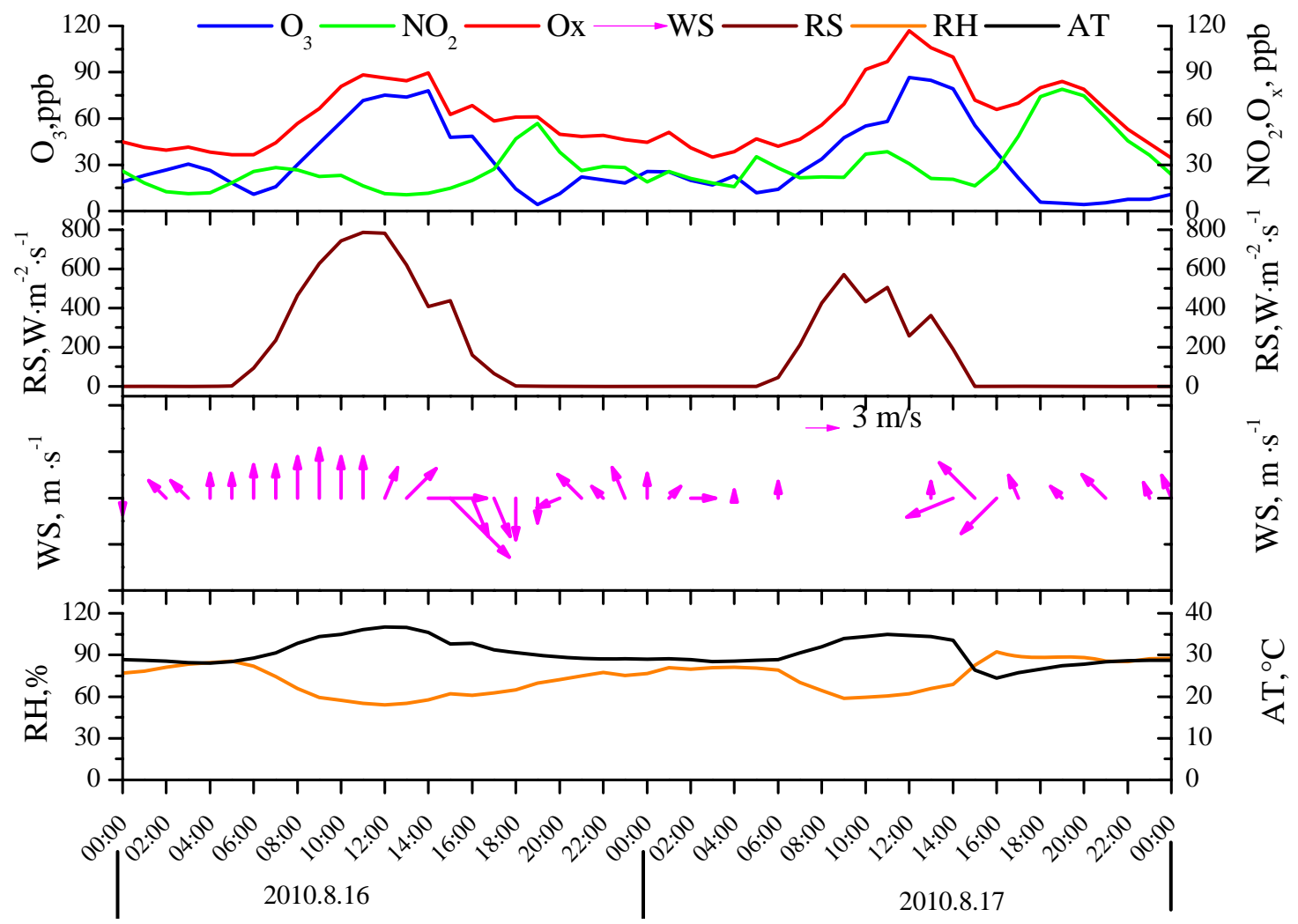

Fig. 16. Time series of meteorological conditions and mass concentrations that observed at $\mathrm{SAES}$ monitoring site during the high $\mathrm{O}_{3}$ pollution episode during 16-17 August 2010. (RS: solar radiation intensity; WS: wind speed; AT: air temperature; RH: relative humidity)

The model evaluation indicates an overall acceptable performance although some bias in the simulation of both meteorological parameters and the air pollutant concentrations exist. These model biases may affect process analysis results to some extent. Nevertheless, the analysis can provide valuable insights into the governing processes that control $\mathrm{O}_{3}$ concentrations, which will give a useful way in guiding the $\mathrm{O}_{3}$ control measures. 

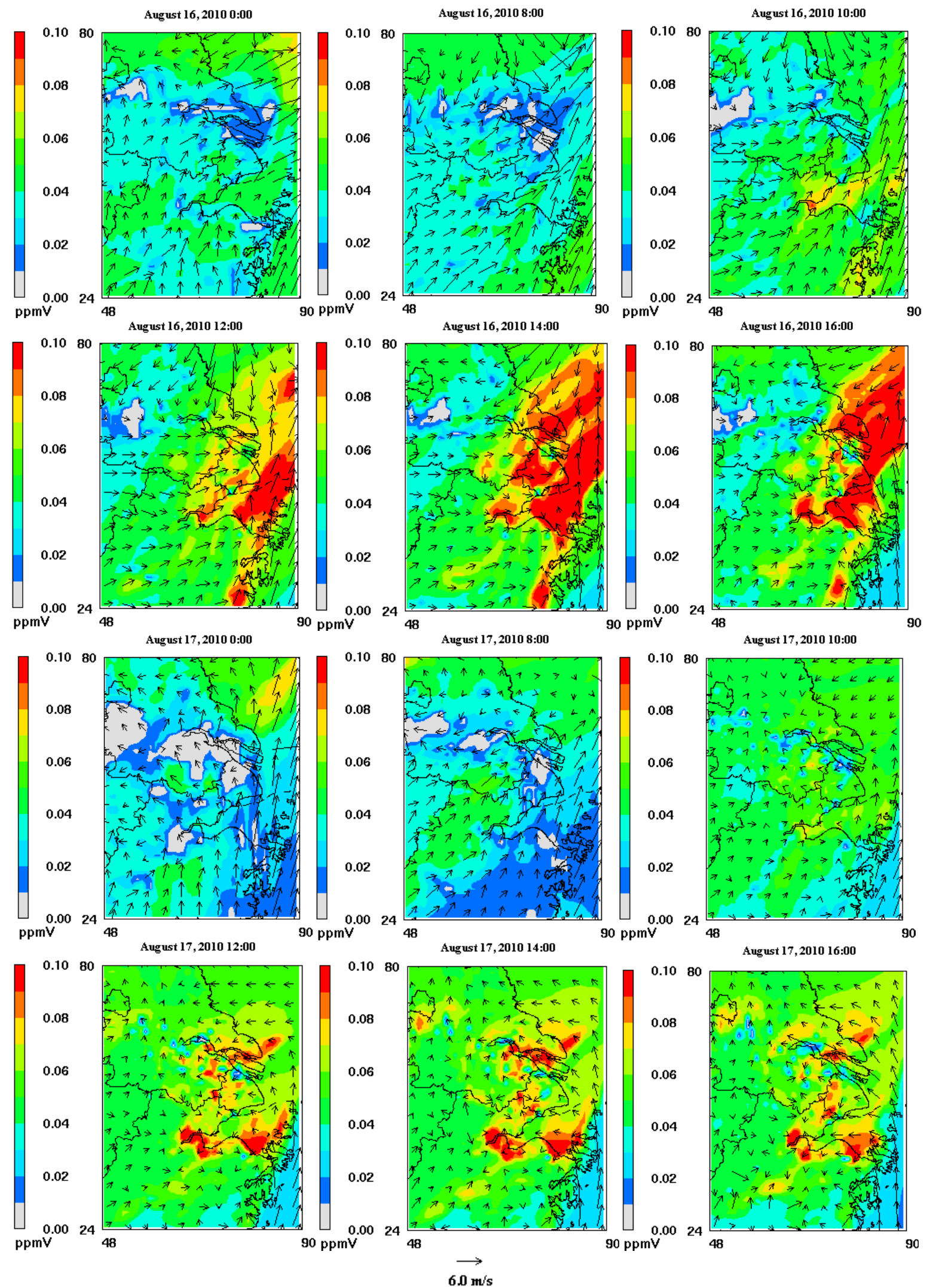

Fig. 17. Regional ozone transport during the high $\mathrm{O}_{3}$ pollution episode during 16-17 August 2010. 
Supplementary material related to this article is available online at: http://www.atmos-chem-phys.net/12/ 10971/2012/acp-12-10971-2012-supplement.pdf.

Acknowledgements. This study was supported by the National Non-profit Scientific Research Program for Environmental Protection via grant No. 201009001 and 201209001, the Science and Technology Commission of Shanghai Municipality Fund Project via grant No. 11231200500, and the National Natural Science Foundation of China (NSFC) via grant No. 41205122 and No. 41105102. The authors appreciate the suggestions made by the reviewers that helped greatly to improve this paper.

Edited by: C. K. Chan

\section{References}

An, X., Zhu, T., Wang, Z., Li, C., and Wang, Y.: A modeling analysis of a heavy air pollution episode occurred in Beijing, Atmos. Chem. Phys., 7, 3103-3114, doi:10.5194/acp-7-3103-2007, 2007.

Borge, R., López, J., Lumbreras, J., Narros, A., and Rodríguez, E.: Influence of boundary conditions on CMAQ simulations over the Iberian Peninsula. Atmos. Environ., 44, 2681-2695, 2010.

Byun, D. and Schere, K. L.: Review of the governing equations, computational algorithms, and other components of the Models3 Community Multiscale Air Quality (CMAQ) modeling system, Appl. Mech. Rev., 59, 51-77, 2006.

Chou, C. C.-K., Tsai, C.-Y., Chang, C.-C., Lin, P.-H., Liu, S. C., and Zhu, T.: Photochemical production of ozone in Beijing during the 2008 Olympic Games, Atmos. Chem. Phys., 11, 9825-9837, doi:10.5194/acp-11-9825-2011, 2011.

Emery, C. A., Tai, E., and Yarwood, G.: Enhanced meteorological modeling and performance evaluation for two Texas ozone episodes, Project Report prepared for the Texas Natural Resource Conservation Commissions, ENVIRON International Corporation, Novato, CA, USA, 2001.

Foley, K. M., Roselle, S. J., Appel, K. W., Bhave, P. V., Pleim, J. E., Otte, T. L., Mathur, R., Sarwar, G., Young, J. O., Gilliam, R. C., Nolte, C. G., Kelly, J. T., Gilliland, A. B., and Bash, J. O.: Incremental testing of the Community Multiscale Air Quality (CMAQ) modeling system version 4.7, Geosci. Model Dev., 3, 205-226, doi:10.5194/gmd-3-205-2010, 2010.

Fu, J. S., Jang, C. J., Streets, D. G., Li, Z., Kwok, R., Park, R., and Han, Z.: MICS-Asia II: Modeling gaseous pollutants and evaluating an advanced modeling system over East Asia, Atmos. Environ., 42, 3571-3583, 2008.

Goncalves, M., Jimenez, G. P., and Baldasano, J. M.: Contribution of atmospheric processes affecting the dynamics of air pollution in South-Western Europe during a typical summertime photochemical episode, Atmos. Chem. Phys., 9, 849-864, doi:10.5194/acp-9-849-2009, 2009.

Huang, C., Chen, C. H., Li, L., Cheng, Z., Wang, H. L., Huang, H. Y., Streets, D. G. and Wang, Y. J.: Emission inventory of anthropogenic air pollutants and VOCs species in the Yangtze River Delta region, China, Atmos. Chem. Phys., 11, 4105-4120, doi:10.5194/acp-11-4105-2011, 2011.
Jiménez, P., Parra, R., Baldasano, M.J.: Influence of initial and boundary conditions for ozone modelling in very complex terrains: a case study in the northeastern Iberian Peninsula. Environmental Modelling and Software 22, 1294-1306, 2007.

Li, L., Chen, C. H., Fu, J. S., Huang, C., Streets, D. G., Huang, H. Y., Zhang, G. F., Wang, Y. J., Jang, C. J., Wang, H. L., Chen, Y. R., and Fu, J. M.: Air quality and emissions in the Yangtze River Delta, China, Atmos. Chem. Phys., 11, 16211639, doi:10.5194/acp-11-1621-2011, 2011a.

Li, L., Chen, C. H., Huang, C., Huang, H. Y., Zhang, G. F., Wang, Y. J., Chen, M. H.,Wang, H. L., Chen, Y. R., Streets, D. G., and Fu, J. M.: Ozone sensitivity analysis with the MM5-CMAQ modeling system for Shanghai, J. Environ. Sci., 23, 1150-1158, 2011b.

Liu, X. H., Zhang, Y., Cheng, S. Y., Xing, J., Zhang, Q., Streets, D. G., Jang, C., Wang, W. X., and Hao, J. M.: Understanding of regional air pollution over China using CMAQ, part I: performance evaluation and seasonal variation, Atmos. Environ., 44, 2415-2426, 2010.

Ran, L., Zhao, C., Geng, F., Tie, X., Tang, X., Peng, L., Zhou, G., Yu, Q., Xu, J., and Guenther, A.: Ozone photochemical production in urban Shanghai, China: Analysis based on ground level observations, J. Geophys. Res., 114, D15301, doi:10.1029/2008JD010752, 2009.

Sarwar, G., Luecken, D., Yarwood, G., Whitten, G. Z., and Carter, W. P. L.: Impact of an Updated Carbon Bond Mechanism on Predictions from the CMAQ Modeling System: Preliminary Assessment. J. Appl. Meteor. Climatol., 47, 3-14, doi:10.1175/2007JAMC1393.1, 2008.

Seinfeld, J. H. and Pandis, S. N.: Atmospheric Chemistry and Physics: From Air Pollution to Climate Change (Second Edition), John Wiley \& Sons, New York, USA, 204-283, 2006.

Shao, M., Zhang, Y. H., Zeng, L. M., Tang, X. Y., Zhang, J., Zhong, L. J., and Wang, B. G.: Ground-level ozone in the Pearl River Delta and the roles of $\mathrm{VOC}$ and $\mathrm{NO}_{\mathrm{x}}$ in its production, J. Environ. Manage., 90, 512-518, 2009.

Shen, J., Wang X. S., Li, J. F., Li, Y. P., and Zhang, Y. H.: Evaluation and intercomparison of ozone simulations by Models-3/CMAQ and CAMx over the Pearl River Delta, Sci. China (Chem.), 54, 1789-1800, 2011.

Streets, D. G., Bond, T. C., Carmichael, G. R., Fernandes, S. D., Fu, Q., He, D., Klimont, Z., Nelson, S. M., Tsai, N. Y., Wang, M. Q., Woo, J. H., and Yarber, K. F.: An inventory of gaseous and primary aerosol emissions in Asia in the year 2000, J. Geophys. Res., 108, 8809, doi:10.1029/2002JD003093, 2003a.

Streets, D. G., Yarber, K. F., Woo, J.-H., and Carmichael, G. R.: Biomass burning in Asia: annual and seasonal estimates and atmospheric emissions, Global Biogeochem. Cy., 17, 1099, doi:10.1029/2003GB002040, 2003 b.

Tang, G., Li, X., Wang, Y., Xin, J., and Ren, X.: Surface ozone trend details and interpretations in Beijing, 2001-2006, Atmos. Chem. Phys., 9, 8813-8823, doi:10.5194/acp-9-8813-2009, 2009.

Wang, H., Kiang, C. S., Tang, X., Zhou, X., and Chameides, W.: Surface ozone: A likely threat to crops in Yangtze delta of China, Atmos. Environ., 39, 3843-3850, 2005.

Wang, K., Zhang, Y., Jang, C., Phillips, S., and Wang, B. Y.: Modeling intercontinental air pollution transport over the transPacific region in 2001 using the Community Multiscale Air Quality modeling system, J. Geophys. Res., 114, D04307, doi:10.1029/2008JD010807, 2009a. 
Wang, L. T., Jang, C., Zhang, Y., Wang, K., Zhang, Q., Streets, D. G., Fu, J., Lei, Y., Schreifels, J., He, K. B., Hao, J. M., Lam, Y. F., Lin, J., Meskhidze, N., Voorhees, S., Evarts, D., and Phillips, S.: Assessment of air quality benefits from national air pollution control policies in China - Part II: Evaluation of air quality predictions and air quality benefits assessment, Atmos. Environ., 44, 3449-3457, 2010.

Wang, T., Ding, A. J., Gao, J., and Wu, W. S.: Strong ozone production in urban plumes from Beijing, China, Geophys. Res. Lett., 33, L21806, doi:10.1029/2006GL027689, 2006.

Wang, T., Nie, W., Gao, J., Xue, L. K., Gao, X. M., Wang, X. F., Qiu, J., Poon, C. N., Meinardi, S., Blake, D., Wang, S. L., Ding, A. J., Chai, F. H., Zhang, Q. Z., and Wang, W. X.: Air quality during the 2008 Beijing Olympics: secondary pollutants and regional impact, Atmos. Chem. Phys., 10, 7603-7615, doi:10.5194/acp10-7603-2010, 2010a.

Wang, X., Zhang, Y., Hu, Y., Zhou, W., Lu, K., Zhong, L., Zeng, L., Shao, M., Hu, M., and Russell, A. G.: Process analysis and sensitivity study of regional ozone formation over the Pearl River Delta, China, during the PRIDE-PRD2004 campaign using the Community Multiscale Air Quality modeling system, Atmos. Chem. Phys., 10, 4423-4437, doi:10.5194/acp-10-4423-2010, 2010b.

Wang, Y., Hao, J., McElroy, M. B., Munger, J. W., Ma, H., Chen, D., and Nielsen, C. P.: Ozone air quality during the 2008 Beijing Olympics-effectiveness of emission restrictions, Atmos. Chem. Phys., 9, 5237-5251, doi:10.5194/acp-9-5237-2009, 2009b.

$\mathrm{Xu}$, J. and Zhang, Y. H.: Process analysis of $\mathrm{O}_{3}$ formation in summer at Beijing, Acta Sci. Circumst., 26, 973-980, 2006.

Xu, J., Zhang, Y. H., and Wang, W.: Numerical study on the impacts of heterogeneous reactions on ozone formation in the Beijing urban area, Adv. Atmos. Sci., 23, 605-614, 2006.

Xu, J., Zhang, Y., Fu, J. S., and Wang, W.: Process Analysis of Typical Ozone Episode in Summer over Beijing Area, Sci. Total Environ., 399, 147-157, 2008.

Xu, X. B., Lin, W. L., Wang, T., Meng, Z. Y., and Wang, Y.: Longterm Trend of Tropospheric Ozone over the Yangtze Delta Region of China, Adv. Clim. Change Res., 3(Suppl.), 60-65, 2007.
Yarwood, G., Roa, S., Yocke, M., and Whitten, G.: Updates to the Carbon Bond Chemical Mechanism: CB05. Final report to the US EPA, RT-0400675, available at: http://www.camx.com, 2005.

Zhang, Y., Liu, P., Queen, A., Misenis, C., Pun, B., Seigneur, C., and Wu, S. Y.: A comprehensive performance evaluation of MM5CMAQ for the Summer 1999 Southern Oxidants Study episodePart II: Gas and aerosol prediction, Atmos. Environ., 40, 48394855, 2006.

Zhang, Q., Streets, D.G., Carmichael, G. R., He, K. B., Huo, H., Kannari, A., Klimont, Z., Park, I. S., Reddy, S., Fu, J. S., Chen, D., Duan, L., Lei, Y., Wang, L. T., and Yao, Z. L.: Asian Emissions in 2006 for the NASA INTEX-B Mission, Atmos. Chem. Phys., 9, 5131-5153, doi:10.5194/acp-9-5131-2009, 2009a.

Zhang, Y., Vijayaraghavan, K., Wen, X. Y., Snell, H. E., and Jacobson, M. Z.: Probing into regional ozone and particulate matter pollution in the United States: 1. A 1 year CMAQ simulation and evaluation using surface and satellite data, J. Geophys. Res., 114, D22304, doi:10.1029/2009JD011898, 2009b.

Zhang, Y., Vijayaraghavan, K., Wen, X. Y., Snell, H. E., and Jacobson, M. Z.: Probing into regional $\mathrm{O}_{3}$ and particulate matter pollution in the United States: 2. An examination of formation mechanisms through a process analysis technique and sensitivity study, J. Geophys. Res., 114, D22305, doi:10.1029/2009JD011900, 2009c.

Zhang, Y. H., Su, H., Zhong, L. J., Cheng, Y. F., Zeng, L. M., Wang, X. S., Xiang, Y. R., Wang, J. L., Gao, D. F., Shao, M., Fan, S. J., and Liu, S. C.: Regional ozone pollution and observation-based approach for analyzing ozone-precursor relationship during the PRIDE-PRD2004 campaign, Atmos. Environ., 42, 6203-6218, 2008.

Zhao, C. S., Peng, L., Sun, A. D., Qin, Y., Liu, H. L., Li, W. L., and Zhou, X. J.: Numerical modeling of tropospheric ozone over Yangtze Delta region, Acta Sci. Circumst., 24, 525-533, 2004. 